\title{
Kazimierz Śmigiel
}

\section{Sytuacja prawna Kościoła katolickiego w Kraju Warty}

Prawo Kanoniczne : kwartalnik prawno-historyczny 21/1-2, 157-194

1978

Artykuł został zdigitalizowany i opracowany do udostępnienia w internecie przez Muzeum Historii Polski w ramach prac podejmowanych na rzecz zapewnienia otwartego, powszechnego i trwałego dostępu do polskiego dorobku naukowego i kulturalnego. Artykuł jest umieszczony w kolekcji cyfrowej bazhum.muzhp.pl, gromadzącej zawartość polskich czasopism humanistycznych i społecznych.

Tekst jest udostępniony do wykorzystania w ramach dozwolonego użytku. 
KS. KAZIMIERZ SMIGIEL

\section{SYTUACJA PRAWNA KOSCIOEA KATOLICKIEGO W KRAJU WARTY}

Treśc: 1. Założenia nowej struktury prawnej. 2. Rozporządzenie namiestnika Rzeszy o stowarzyszeniach religijnych i związkach religijnych z 13. IX 1941 roku. 3. Stosunek rozporządzenia z 13. IX. $1941 \mathrm{r}$. do prawa kanonicznego. 4. Stosunek Stolicy Apostolskiej do sytuacji prawnej. 5. Skutki kanoniczne rozporządzenia z 13. IX. 1941 roku. 6. Statuty katolików niemieckich. 7. Statut polskiego stowarzyszenia religijnego. 8. Stan „przejsciowy” do końca okupacji.

\section{Założenia nowej struktury prawnej}

Sytuację prawną Kościoła katolickiego określał Konkordat zawarty pomiędzy rządem polskim a Stolicą Apostolską w 1925 r. Konkordat polski jako część składowa polskiego systemu prawnego miał podzielić losy polskiego prawa $w$ ogble. Wprawdzie ustawodawca niemiecki anektując ziemie zachodnie do Rzeszy dekrєtem inkorporacyjnym z 8. X. 1939 r. w $\S 7$ pozostawiał prawo polskie dalej w mocy w miare stopniowego zastępowania go przez ustawy niemieckie. Jednakże ten przepis mial znaczenie teoretyczne tylko, bowiem przywódcy hitlerowscy praktyką „contra legem" przełamali zasadę dalszego obowiązywania prawa polskiego ${ }^{1}$. Wedlug namiestnika Rzeszy Greisera w dziedzinie prawno-kościelnej istniała na początku 1940 r. następująca sytuacja 2:

1. Ani Rzesza Niemiecka ani okręg Kraj Warty nie jest następcą prawnym polskiego państwa.

2. Namiestnik Rzeszy decyduje $w$ porozumieniu $z$ ministrem spraw wewnętrznych, jakie prawo zastosuje: prawo polskie ,prawo Rzeszy, czy też prawo ustanowione w Kraju Warty do przeobrażenia struktur

1 Reichsgesetzblatt I 1939, s. 2042. Przedruk: P os p i e s z a l s k i K. M., Hitlerowskie „prawo” okupacyjne $w$ Polsce. Wybór dokumentów. Częśc I Ziemie „wcielone”, Poznań 1952, s. 84; tenże, Polska pod niemieckim prawem 1939-1945 (Ziemie Zachodnie), Poznań 1946, s. 30-35.

2 C o n w a y. S., Nationalsozialistische Kirchenpolitik 1939-1945. Ihre Ziele, Wiedersprüche und Fehlschläge, München 1969, s. 330, G r e iser do ministra Rzeszy Kerrla 5 II 1940. 
3. W Kraju Warty nie będą zastosowane normy obowiązujące w Stąrej Rzeszy.

4. Kościoly wielkopolskie otrzymają nowy status prawny - stowarzyszeń religijnych.

Wychodząc z założenia, że moc obowiązująca prawa polskiego skończyła się razem $\mathrm{z}$ upadkiem niepodległości, G re is er akcentował zasadę istniejącej „pustki” prawnej, co wyrażało się w hasle: rechtfreie Raum ${ }^{3}$. Tę pustkę mial wypelnic zaprogramowany nowy system prawny Kosciołów. Jego celem był ,całkowity rozdzial” Koscioła od państwa, czyli rozdzial ,sui generis", odpowiadający przesłankom narodowego socjalizmu i jego totalitarnym roszczeniom. Nie byl to jednak cel sam w sobie, lecz ogniwo pośrednie w walce z Kosciolami, „kamień milowy” na drodze do zupelnego ich zlikwidowania 4

Pierwszym, oficjalnym momentem polityki koscielnej w sprawie postulowanego statusu prawnego było rozporządzenie namiestnika Rzeszy o ordynacji skzadkowej z 14. III. 1940 r. (Verordnung über die Erhebung von Beiträgen durch religiöse Vereinigungen und Religionsgesellschaften) ${ }^{5}$. Tresć tego rozporzadzenia sprowadzała się do normatywów odnoszących się do finansowania kosciołów i nadzoru państwowego. Jednakże jego istotne znaczenie, zdaniem referenta spraw koscielnych w urzędzie namiestnika Rzeszy $D u d z u s a$, polegało na tym, ze został dokonany przelom w zakresie statusu prawnego Kościolów, które zostaną zminoryzowane do płaszczyzny stowarzyszeń prywatnych.

Charakteristicum polityki wyznaniowej wladz hitlerowskich Kraju Warty, rozważanej $w$ aspekcie zamierzeń, stanowi program „13 punktów". Celem ich było nowe uregulowanie sytuacji prawnej społecznosci wyznaniowych i z tego punktu widzenia zostały nazwane ,programem". Geneza programu nie jest $w$ sposób pewny wyjaśniona, jeđnakże prawie ogolnie się przypuszcza, ze został przygotowany w kancelarii monachijskiej NSDAP?. Treśc programu nie jest ujęciem całokształtu polityki koscielnej, lecz raczej minimalnym programem z ukierunkowaniem na status prawny, chociaż zawiera również punkty, które wykraczaja

${ }^{3}$ G ürtler P., Nationalsozialismus und evangelische Kirchen im Warthegau. Trennung von Staat und Kirche im nationalsozialistischen Weltanschauungsstaat, Göttingen 1958, s. 37-43.

4 Na konferencji 4 IX 1940 r., G re is e r oswiadczył, że ,idea państwa narodowosocjalistycznego wymaga rozdziału Kosciola od państwa". Tamże, s. 55.

5 Verordnungsblatt des Reichsstatthalters im Reichsgau Wartheland (skrót: VOBL) 1940, s. 229-230.

- Gürtler, dz. cyt., s. 45.

7 Stasiewski B., Die Kirchenpolitik der Nationalsozialisten im Warthegau 1939-1945, Vierteljahrshefte für Zeitgeschichte H. 1/1959, $\mathbf{s}$. 53; G ürtl e r, dz. cyt., s. 48, przypis 114. J. Sziling, Polityka okupanta hitlerowskiego wobec Kościola katolickiego 1939-1945. Tzw. Okręgi Rzeszy: Gdansk - Prusy Zachodnie, Kraj Warty i regencja katowicka, Poznań 1970, s. 43, przypis 82, przypuszcza, ze program powstal w urzędzie namiestnika Rzeszy w Poznaniu. 
poza zakres sytuacji prawnej i posiadają cechy eksterminacyjne, np. zapowiedź totalnej likwidacji zakonów. „13 punktów” są również charakterystyczne pod względem sformułowań, które po raz pierwszy znalazły się $w$ oficjalnym oświadczeniu przedstawicieli narodowego socjalizmu. Punkty nie zostały przekazane $w$ formie piśmiennej, zostały bowiem tylko podane do wiadomości członkom konsystorza ewangelickiego w Poznaniu przez referenta spraw kościelnych Dudzusa na konferencji w urzędzie namiestnika Rzeszy dnia 10. VII. 1940 r.:

1. „Nie ma Kościołów w pojęciu ogólnopaństwowym, lecz istnieją tylko związki religijne w sensie stowarzyszenia". Referent spraw koscielnych dodal, że Kościoły przestają być korporacją prawa publicznego. Pierwotnie zamierzano pozostawić Kościołowi status prawno-publiczny niższej rangi $w$ stosunku do osobowości prawnej państwa, lecz odstąpiono od tego zamiaru. W rozporządzeniu o ordynacji składkowej $z$ dnia 14. III. 1940 r. zastała usankcjonowana nowa terminologia $z$ pominięciem nazwy „Kościół”. •

2. „Kierownictwem tych związków religijnych nie zajmują się urzędy („Behörden”), lecz zarządy stowarzyszen”" („Vereinsvorständen”).

3. $Z$ tego powodu nie istnieją $w$ owym zakresie żadne ustawy ani żadne rozporządzenia lub zarządzenia". Referent spraw kościelnych dodal: nie będzie podatku kościelnego, tylko podstawą uposażenia Kościoła będa członkowskie składki („Kirchenbeiträge”).

4. „Nie istnieją żadne stosunki z grupami poza „Gauem” ani też żadne powiązania natury prawnej, finansowej lub służbowej z Kościołem Rzeszy". Uzupełnienie: Kościoły w Kraju Warty mają być „niezależne”. Związek Kosciola katolickiego z Watykanem będzie rozwiązany.

5. „Członkami stowarzyszenia mogą zostać tylko osoby pełnoletnie $i$ to na podstawie pisemnej deklaracji o swoim przystąpieniu. Nie sa oni więc członkami z samego urodzenia, lecz mogą nimi zostać dopiero po osiągnięciu pełnoletnosci i złożeniu odpowiedniego oświadczenia. Nie ma żadnych Kościołów krajowych, narodowych lub terytorialnych. Kto $z$ Altreichu przybywa do Warthegau, także musi się na nowo wpisać do stowarzyszenia religijnego".

6. „Znosi się i zabronione są wszystkie wyznaniowe podgrupy $z$ ich odgałęziami (grupy młodzieżowe)". Referent spraw kościelnych: zadnych stowarzyszeń wspomagających prawę parafialną. Nic nie może stać na przeszkodzie wychowaniu do wspólnoty narodowej".

7. „Niemcom i Polakom nie wolno się razem gromadzić w kościele (zasada narodowościowa). Postanowienie to po raz pierwszy nabiera mocy obowiązującej dla narodowego socjalizmu". Uwaga referenta: dotyczy Kościołów ewangelickich i katolickiego, musi być dokonany ścisły rozdzial pomiędzy polskoscią a niemczyzną.

8. „W szkołach nie wolno uczyć katechezy konfirmacyjnej (,Konfirmandenunterricht"). Według referenta spraw kościelnych ten punkt odnosi się $\mathrm{w}$ ogóle do nauki religii w szkołach. 
9. „Z wyjątkiem składek, wpłacanych przez stowarzyszonych, wzbronione są jakiekolwiek inne dofinansowania". Uzupełnienie: nowe prawo utrudni przeprowadzenie zbiórek kościelnych. Kolekty będą zlikwidowane. Finanse kościelne zostaną poddane kontroli czynników państwowych.

10. „Z wyjątkiem pomieszczeń potrzebnych do odprawiania religijnego kultu stowarzyszeniom nie wolno posiadać żadnych budowli, budynkow, roli i cmentarzy". Referent spraw koscielnych uzupełnil: jest zamierzona konfiskata kościelnej własności ziemskiej. Cmentarz jest dokumentem wspólnoty narodowej, pochówki wedlug kategorii wyznaniowych rozbijają tę wspólnotę.

11. „Stowarzyszeniom nie wolno się udzielać na polu opieki społecznej, ponieważ to jest wyłącznie dziedzina pracy dla NSV".

12. „Wszystkie zakłady religijne i stowarzyszenia zakonne podlegają rozwiązaniu, ponieważ są sprzeczne $\mathrm{z}$ niemieckim pojęciem obyczajności i z polityką narodowościową".

13. „W stowarzyszeniach mogą być czynni wyłącznie duchowni urodzeni $w$ Warthegau, którzy jednak nie są duchownymi w pełnym tego slowa znaczeniu, bo muszą posiadać i wykonywać także zawód swiecki" 8.

Te postulaty zostały jeszcze obszerniej zareferowane na konferencji zorganizowanej dnia 26. XI. 1940 r. w urzędzie namiestnika Rzeszy w Poznaniu, której przewodniczył referent spraw kościelnych Dudzus. Treść konferencji w istocie rzeczy pokrywa się z programem 13 punktów, nie mniej istnieją bardziej szczegółowe sformułowania, zwłaszcza w odniesieniu do „polskiego” Koscioła katolickiego i systemu opieki religijnej poszczególnych związków religijnych. Według zamierzeń władz nowe prawo wyznaniowe ma wejść $w$ życie $z$ końcem 1940 roku. Wszystkie organizacje religijne w Kraju Warty nie będą potraktowane na równi ze związkami religijnymi w Starej Rzeszy, bowiem ich status prawny nie będzie odpowiadał korporacji prawa publicznego. Ewangelickie konsystorze i katolickie kurie przestaną istnieć. Egzystencja tych instytucji będzie miała charakter tylko przejsciowy. Novum polega na tym, że odtąd istnieć będą tylko lokalne stowarzyszenia wyznaniowe („Konfessionalelle Ortsvereinen”) nie jako instytucje publiczne, Jecz ich status prawny opierać się będzie na prawie cywilnym. Program 13 punktów stwierdził ogólnie, że w przyszlości istnieć będą religijne stowarzyszenia na prawie cywilnym, natomiast dokładniej nie okreslał ich

8 Zarówno tekst programu jak i uzupełnienia referenta spraw kościelnych według $G$ ürtle r a, dz. cyt., s. 47-51. W odniesieniu do punktu 13 G ürtler się zastrzega, ze na konferencji 10 VII 1940 r. w tym miejscu byla mowa, że niemiecki uniwersytet poznański nie będzie posiadał wydziału teologicznego i że powstanie ewangelickie studium $w$ Poznaniu, lecz bez oznaczenia „Hochschule”. G ü r tl e r przyjął tekst 13 punktu z obiegowej wersji programu.

J. Sziling, dz. cyt., s. $45-46$ omawia program 13 punktów. 
zakresu. Tutaj mowa o organizacjach lokalnych, które obejmują poszczególne miasta czy obwody urzędowe. Żródlem utrzymania tych lokalnych stowarzyszeń będą składki członkowskie, egzekwowane na podstawie zatwierdzonej ordynacji składkowej. Stowarzyszeniom nie wolno przeprowadzać zbiórek pieniężnych lub przyjmować fundacji. Państwo zastrzega sobie $w$ ten sposób kontrolę finansów kościelnych. Wszelkie dofinansowanie Kosciołów przez organy państwowe i komunalne nie będzie możliwe. Pomoc państwa może byé tylko zagwarantowana $w$ sposób tymczasowy - w odniesieniu do tych stowarzyszeń, ktore skupiają małą liczbę członków i nie mogłyby same się utrzymać. Wartoś dochodów w ramach zatwierdzonej ordynacji składkowej nie moze byc ta sama dla niemieckich i polskich stowarzyszeń religijnych. Skladki polskich stowarzyszeń powinny pokrywać tylko wydatki rzeczowe, bowiem działalność duszpasterska księży ma być zajęciem dodatkowym.

Opieka religijna $w$ ramach poszczegolnych Kosciołow jest znacznie zróżnicowana. Według oceny niemieckich czynnikbw państwowych sytuacja jest dobra $w$ odniesieniu do wyznania ewangelickiego i polskich katolików, nie jest zaś wystarczająca w stosunku do katolików Niemców. Na tym odcinku jest niezbędna pewna pomoc, lecz tymczasowa, przez duchownych sprowadzanych ze "Starej Rzeszy". Z opieką religijną lączy się kwestia duchowieństwa, które w przyszłości musi być rodzime. Przygotowanie kleru do zawodu może się odbywać w ramach poszczególnych stowarzyszeń lokalnych, które jednak nie mogą tworzyć wspólnych związków celem kształcenia duchowieństwa. W Poznaniu nie powstanie wydzial teologiczny, państwo bowiem nie chce dopuścić, aby $w$ przyszłości duchowny posiadał wykształcenie akademickie.

O przynależności do stowarzyszenia decyduje nie chrzest, lecz deklaracja o wstąpieniu. O wstąpieniu czy wystąpieniu $z$ stowarzyszenia zglasza się lokalnym władzom administracyjnym. Jakakolwiek propaganda na rzecz wstąpienia lub wystąpienia jest zakazana.

Więcej uwagi poswięcił referent spraw koscielnych polityce finansowej $w$ odniesieniu do związków religijnych $w$ łącznosci $z$ ich reorganizacją. Minister do Spraw Kościelnych Rzeszy przeznaczył w ubieglym roku budżetowym sumę 450000 Marek ze skarbu państwa na cele koscielne. Namiestnik Rzeszy zgodnie z przyjętym założeniem, że państwo nie dofinansowuje Kościołów, sprzeciwił się tej formie pomocy i wzmiankowana suma została zamrożona $w$ banku. W nowym roku budżetowym namiestnik Rzeszy zgłosił zapotrzebowanie na fundusz $500000 \mathrm{M}$., którymi sam chce dysponować i przeznaczyé na fakultatywne świadczenia dla celów kościelnych, bowiem rozporządzenia $z$ dnia 14.III.1940 r. wyklucza prawo związków religijnych do świadczeń z budżetu państwowego. Whrew postanowieniom rozporządzenia o ordynacji składkowej przyznającemu prezydentom regencji uprawnienia do nad- 
zoru spraw finansowych związków religijnych, namiestnik Rzeszy również zarządził, aby na tym etapie przejsciowym do nowej struktury prawnej, polityka finansowa $w$ odniesieniu do Kosciolów, była prowadzona centralnie, tzn. przez urząd namiestnika. $Z$ góry wysunięto postulat, aby wartość dochodu $w$ ramach zatwierdzonych ordynacji składkowych nie była równa dla polskich i niemieckich związków.

W sprawach nauczania religii w szkołach i konfiskaty własnosci kościelnej stanorwisko jest identyczne z programem „13 puniktów" i nie wnosi nowych szczególów.

Gdy idzie o egzekutywę, referent spraw kościelnych przedstawił zamierzenia wladz niemieckich na najbliższy okres:

1. nowe prawo uksaże się prawdopodobnie pod koniec roku,

2. władze zwierzchnie polskich związków religijnych zostaną natychmiast zlikwidowane, niemieckich zas związków ulegną stopniowej likwidacji,

3. przystąpi się do zajęcia wszelkiej własności kościelnej poza budynkami kultowymi,

4. w związku $z$ nową sytuacją prawną tajna policja państwowa i służba bezpieczeństwa $w$ porozumieniu się $z$ prezydentami regencji przygotuje do stycznia $1941 \mathrm{r}$. nowy plan rozdzielczy dla polskich duchownych ${ }^{9}$.

W zasadzie organizowanie nowego porządku prawnego odnosiło się w pierwszym rzędzie do niemieckich Kościołów chrześcijańskich: katolickiego, ewangelicko-unijnego i ewangelicko-augsburskiego. Mniejsze spoleczności wyznaniowe miały również otrzymać w dalszej przyszłości uznanie prawne, a jednocześnie władze okupacyjne rozważały możliwość wykorzystania ich jako stymulatorów do wywarcia presji na większe organizacje. Dotyczyło to uzgodnienia szczegółowych postanowień statutowych. Ta sprawa stała się dopiero aktualna po wydaniu rozporządzenia o związkach religijnych.

Zgola specyficzny był stosunek władz okupacyjnych do Kościola katolickiego Polaków. Greiser chciał udzielić statusu prawnego w porozumieniu z Kancelarią Partii i po uzyskaniu zgody Bormanna. Jednak wladze okupacyjne nie zamierzały stwarzać organizacji parytatywnej w stosunku do niemieckich związków religijnych. Główne podloże odrębnego potraktowania polskiego Kościoła opierało się na jego licznych powiązaniach $\mathrm{z}$ polskością $\mathrm{i} z$ niego wynikało istotne założenie, aby wykluczyć możliwość utworzenia organizacji do działalności antyniemieckiej (Aufbau einer Widerstandsorganisation"). Te tendencje miały znaleźć szczególawy wyraz w uprawnieniach tego Kościoła, w statucie i ordynacji skladkowej. Nawet w przypadku gdyby plany okupanta doszły do skutku, aktualna sytuacja duszpasterska i stan liczbowy duchowieństwa nie mial ulec żadnym zmianom. Te zamierzenia po-

9 Archiwum Pánstwowe Miasta Łodzi i Województwa Éodzkiego, (skrót: AGE) Reg. Łódzka 792, 66-71. 
chodza $\mathrm{z}$ drugiej połowy 1942 roku. Zatem mialaby to byc nie tylko organizacja z minimalnymi uprawnieniami, ale faktycznie Kościól ,szczątkowy" 10 .

Od początku 1941 r. wladze okupacyjne zamierzały pod wpływem presji zmusić związki religijne do dokonania przeobrażeń prawnych zgodnie $z$ postulatami namiestnika Rzeszy. $Z$ jednej strony domagano się inicjatywy ze strony związków religijnych, z drugiej zaś strony nie sprecyzowano warunków, jakie miały być przez nie spełnione. Żądania władz okupacyjnych stały $w$ lączności z szeregiem zarządzeń, które ograniczały działalność Kościolớw - przede wszystkim podcinały ich egzystencję materialną.

6. II. 1941 został wydany zakaz zbierania kolekt w kosciołach, w ogóle dokonywanie wszelkich zbiorek pieniężnych na cele religijne i charytatywne. 1. IV. została zakazana działalnosć katolickich kurii diecezjalnych. W tym samym miesiącu ewanglicko-unijny konsystorz w Poznaniu otrzymał zawiadomienie, że jest instytucją "nieistniejącą". 3. V. Gestapo poznańskie zabroniło użyiwać nazwy „Konsystorz Ewangelicki", w odniesieniu do konsystorza unijnego. 12. V. namiestnik Rzeszy wydał zarządzenie zabraniające podporządkowanym urzędom kontaktów służbowych z „byłymi" konsystorzami i kuriami biskupimi. Okres od maja do wrzesnia 1941 r. zaostrzyl "Kirchenkampf" na wielu odcinkach. Wzmażyla się działalnosć propagandowa prowadzona przez partię narodowo-socjalistyczną przeciwiko Kosciołom. Zostały wydane zarządzenia ograniczające $w$ szerszym stopniu działalnośs nauczycielską Kościołów w zakresie nauki religii i katechezy konfirmacyjnej. Wyszedł zakaz działalnosci religijnej swieckich pomocników poza kosciołami. Te antykoscielne akty byly przygotowaniem do promulgowania rozporządzenia namiestnika Rzeszy o związkach religijnych i stowarzyszeniach religijnych $z$ dnia 13 . IX 1941 roku ${ }^{11}$.

\section{Rozporządzenie namiestnika Rzeszy o stowarzyszeniach religijnych i związkach religijnych z $13 . I X .1941 \mathrm{r}$.}

Treść nowego porządku w zakresie prawa wyznaniowego stanowia: Verordnung des Reichsstatthalters im Wartheland über religiöse Vereinigungen und Religionsgesellschaften im Reichsgau Wartheland vom 13. September 1941 12, Vorschriften zur Durchführung der Verordung über religiöse Vereinigungen und Religionsgesellschaften im Reichsgau

${ }_{10}$ Archiwum Głównej Komisji Badania Zbrodni Hitlerowskich w Polsce. Warszawa (skrót: AGH) 584 (Z) VIII/III, 114-117.

$11 \mathrm{G}$ ü r tle r, dz. cyt., s. 59-71.

12 VOBL - Wartheland 1941, s. 463. Przedruk: P os pieszals is, Hitlerowskie „prawo", s. 319-322. 
Wartheland $\mathrm{z}$ tego samego dnia ${ }^{13}$ oraz $19 . \mathrm{XI} .1941 \mathrm{r}^{14} \mathrm{i} 12.11 .1942 \mathrm{r}^{15}$. Pierwszy $i$ ostatni dokument zostaly opublikowane $w$ organie urzędowym namiestnika Rzeszy $w$ Poznaniu. Istotne znaczenie posiadają 3 wczesniejsze akty, bowiem ostatni dotyczy w znacznej mierze spraw administracyjnych $\mathrm{w}$ związku $\mathrm{z}$ nowym rozporządzeniem.

Rozporządzenie z dnia 13.IX.1941 r. stanowi nowy system prawnokościelny powolując do istnienia cztery stowarzyszenia religijne, mianowicie 3 protestanckie i jedno katolickie: Posener evangelische Kirche deutscher Nationalität im Wartheland, Litzmannstädter evangelische Kirche deutscher Nationalität im Wartheland, Evangelisch-lutherische Kirche deutscher Nationalität im Warthegau-West, Römisch-katholische Kirche deutscher Nationalität im Reichsgau Wartheland. Wymienione Kościoly otrzymują na plaszczyźnie prawno-państwowej osobowość prawną prawa prywatnego ${ }^{10}$ i na tej samej płaszczyźnie wchodzą na miejsce istniejących 1.IX.1939 r. na obszarze Kraju Warty asób protestanckich i katolickiej. Posiadają one charakter tylko niemiecki (§ 1 ust. 1).

Rozporządzenie $\mathrm{z}$ dnia 13.IX. nie sprecyzowało związków religijnych, które zastępują nowe osoby prawne. Dopiero dekret wykonawczy z dnia 19.XI.1941 r. ${ }^{17}$ określa to następstwo prawne $w$ sposób następujący: Poznański Ewangelicki Kosciót wchodzi na miejsce istniejq̨cego przedtem Koscioła Ewangelicko-Unijnego ${ }^{18}$, Łódzki Ewangelicki Kościót na

13 Archiwum Państwowe Miasta Poznania i Województwa Poznańskiego (skrót: APP), Reichsstatthalter (skrót: R), 1176,45.

14 Tamże, 73.

15 VOBI - Wartheland 1942, s. 39-40.

16 Polskie ustawodawstwo rozróżnia osoby fizyczne i osobowość prawną pojętą jako zdolność prawną. Zagadnienie osobowosci prawnej rozpatrujemy $w$ aspekcie historycznym. Podzial osob prawnych na osoby prawne prawa publicznego oraz osoby prawne prawa prywatnego jest stosowany $w$ prawie państw burżuazyjnych. Opiera się ona na rozróznieniu prawa publicznego i prawa prywatnego. Związki religijne uznane przez państwo jako osoby prawne prawa publicznego wchodzą $w$ sfere prawa publicznego, ich autonomia, własne prawa są częścią porządku publicznego, ich uprawnienia zwierzchnie w stosunku do członkow stają się władztwem publicznoprawnym, państwo udziela im swojej ochrony i opieki na rówmi z własnymi celami. Związki religijne jako osoby prawne prawa prywatnego są zwyklymi stowarzyszeniami, pozostaja w sferze prywatnoprawnej (G. J. Ebers, Staat und Kirche im neuen Deutschland, München 1930 , s. 203, 255). W stosunku do Kosciolów w Kraju Warty występuje pojęcie osobny prawnej prawa prywatnego w nowym znaczeniu.

17 APP R 1176, 73.

18 Do roku 1939 Kościół ewangelicko-unijny obejmował protestantów zachodniej Polski. Siedzibą władz zwierzchnich był Poznań. Kościoł skupial ewangelików narodowosoi niemieckiej, poza mniejszą grupą ewangelikow - Polaków, liczącą ok. 40000 dusz, w poludniowych powiatach województwa poznanskiego. Był to Kościól zdecydowanie niemiecki i antypolski. Do roku 1939 nie uregulowal sytuacji prawnej w odrodzonym państwie Polskim. B a r te 1 O., Protestantyzm $w$ Polsce, 
miejsce Kościola Ewangelicko-Augsburskiego ${ }^{19}$, Ewangelicko-Luterski Kościól zamiast Kościoła Ewangelicko-Luterskiego Polski Zachodniej ${ }^{20}$, Rzymskokatolicki Kościót Narodowości Niemieckiej na miejsce Kościoia Rzymskokatolickiego.

W rozporządzeniu $z$ dnia 13.IX. namiestnik Rzeszy przewidywał możliwosć udzielenia osobowości prawnej innym jeszcze związkom religijnym, lecz równieź tylko prawa prywatnego (§ 1 ust. 2). Prawodawca miał tu na mysli wszystkie polskie Kościoly i sekty ${ }^{21}$. Zarówno zrzeszenia religijne, które już otrzymaly osobowość prawną, jak i te, które w przyszłości mogą jeszcze ją otrzymać, przejmują prawa i obowiązki istniejących w chwili wybuchu wojny Kościołów i sekt stosownie do wydanych przez namiestnika rozporządzeń administracyjnych. Przejmowanie praw i obowiązków dokonuje się zgodnie $\mathrm{z}$ ustaloną zasadą następstwa organizacji. Jednakże polski majątek wyznaniowy nie podlega przejęciu. Prawodawca wyjaśnia, że jest to taki majątek, którego właściciel-instytucja wyznaniowa $1.1 \mathrm{X} .1939$ r. składała się wyłącznie lub $w$ większości z Polaków albo też przynajmniej byla pod znacznym polskim wplywiem (§ 1 ust. 3). Co się tyczy niepolskiego majątku wyznaniowego, to tylko własnosć Koscioła ewangelicko-unijnego przechodzi bez specjalnych ustaleń na rzecz Poznańskiego Kościola Ewangelickiego, natomiast pozostałe organizacje wyznaniowe przejmują majątek, jeżeli na wniosek zainteresowanych zostanie uznany jako niepolski 22.

Powołanie do istnienia osoby prawne przedstawiają namiestnikowi statuty, ktory je zatwierdza. Stowarzyszenia religijne, ktore nie otrzymały osobowosci prawnej, a chciałyby ją uzyskać, przedstawiają namiestnikowi statuty razem $z$ wnioskiem o udzielenie osobowosci prawnej (§ 2). Statut powinien zawierać; nazwę i siedzibę spoleczności wyznaniowej, przynależność narodowościową człohków, okreslenie zarzqdu i innych organów oraz sposób ich powolywania, postanowienia dotyczące pełnomocnictwa i odpowiedzialnosci organizacyjnej, i jej rozwiązania $(\$ 3)$.

Warszawa $10 \overline{6} 3$, s. 28; por. G ü u r tl e r, dz. cyt., s. 11-13; F ą k a M., Kościoly protestanckie $w$ Polsce $w$ latach 1918-1972, Prawo Kanoniczne $16(1973)$, s. $47-48$.

19 Kościół ewangelicko-augsburski stanowił najliczniejsze ugrupowanie protestantyzmu $w$ Polsce. Siedziba władz zwierzchnich znajdowała się w Warszawie. Przewodniczył temu Kościolowi bp Bursche. Kierownictwo Kościoła bylo polskie. Prawnopaństwowe stanowisko tego Kościoła okreslał dekret Prezydenta Rzeczypospolitej Polskiej z roku 1936. Niemcy - ewangelicy nie chcieli uznac sytuacji prawnej Koscioła i zamierzali utworzyć oddzielny Kościół z niemieckim kierownictwem w Erodzi. B a rtel dz. cyt., s. 27; G ürtle r, dz. cyt., s. 13-15.

${ }_{20}$ Koscioł ewangelicko-luterski $z$ kierownictwem $w$ Rogożnie obejmowal jedną superintendenturę $z 23$ parafiami. Wiernych liczyl zaledwie 4000 . B a it e l, dz. cyt., s. 29.

21 AAP R 1176-45, dekret wykonawczy z 13 IX 1941.

22 Tamże, 73, dekret wykonawczy z 19 XI 1941. 
Warunkiem powołania do "zarządu" związku religijnego jest brak zastrzeżeń natury politycznej ze strony namiestnika Rzeszy. Jeżeli zas takie istnieją w stosunku do członka zarządu i namiestnik Rzeszy wyda zakaz działalności $w$ określonym związku wyznaniowym, tym samym traci on prawa członka zarządu (§ 4).

Stowarzyszenia religijne tracą $w$ potrójny sposób osobowość prawną: przez samorozwiązanie, w razie otwarcia upadłosci i na skutek rozwiązania przez namiestnika Rzeszy (§ 5).

Sprawie przynależności do wyznaniowej osoby prawnej poświęcają dużo miejsca wspomniane zarządzenie z dnia 13.IX, a przede wszystkim dekrety wykonawcze, które dokładniej określają warunki. Najogólniej pojmując przynależność trzeba rozróżnić dwa sposoby nabycia:

1. przez osobiste zadeklarowanie o wstapieniu do wyznaniowej osoby prawnej ( $\$ 6$ ust. 2 ),

2. nabycie przez fakt zamieszkania w Kraju Warty $w$ chwili promulgacji dekretu namiestnika Rzeszy, jeżeli przedtem okreslona osoba należała do jednej $z$ wymienionych organizacji ( $\$ 7$ ust. 1).

Ten sposób można też nazwać „automatycznym" nabyciem przynaleźności. Niezależnie od sposobu nabycia przynależności członek wyznaniowej osoby prawnej musi być pelnoletni, zamieszkiwać Kraj Warty w sposób stały lub podobny do stałego, wreszcie narodowość czlonka nie może być niezgodna $z$ charakterem narodowościowym związku religijnego ( $\$ 6$ ust. 1). Warunek pełnoletni wyklucza z przynależności prawno skutecznej dzieci i młodzież do lat 21. Te osoby nie moga należeć do związku religijnego ${ }^{23}$. Oczywiście przynależność pojmujemy w sensie prawnopaństwowym.

Zamieszkanie w Kraju Warty stanowi istotny warunek przynależności do zrzeszenia. Dzięki niemu pewna grupa osób po spełnieniu innych warunków nabywa „automatycznie” przynależność do związku religijnego. Ten sposób jest tylko jednorazowy, w przyszłosci bowiem osoby, które osiągają pelnoletnosć lub osiedlają się w Kraju Warty muszą deklarować chęć wstąpienia do organizacji wyznaniowej. Niemcy, którzy 1.IX.1939 r. posiadali niemiecką przynależność państwowa, muszą deklarować chęć wstąpienia do organizacji wyznaniowej. Niemcy, Wolnego Miasta Gdańska, ktb́rzy nabyli niemiecką przynależność państwową z dniem 1.IX.1939 r.24.

Nowy parządek prawny zaprowadza zasadę rozdziału narodowościowego. Istnieją na razie niemieckie organizacje wyznaniowe, do których mogą należeć tylko Niemcy. Jeżeli w przyszłości otrzymają osobowość prawną polskie związki religijne, będą skupiać tylko Polaków. Przez Niemców rozumie prawodawca także członków niemieckiej listy narodowościowej grup III i IV, a więc zniemczonych Polaków, także

23 Zob. przypis 21.

24 Tamże. 
niemieckich przesiedleńców, którzy jeszcze nie posiadają niemieckiego obywatelstwa. Zasady przynależności są te same dla Polaków i Niemców ${ }^{25}$.

Poza jednorazowym, „automatycznym" nabyciem przynależności istnieje wstąpienie zadeklarowane. Deklarację o wstapieniu do zrzeszenia sklada kandydat ustnie lub pisemnie przed urzędnikiem stanu cywilnego. Jeżeli deklaracja jest tylko ustna, urzędnik sporządza protokół. Zasady kompetencji urzędu warunkuje miejsce zamieszkania. Urząd stanu cywilnego bada prawidłowość aktu i jeżeli zostały wypełnione warunki, przekazuje deklarację zainteresowanemu stowarzyszeniu religijnemu. Związeł religijny może odrzucić oświadczenie o wstąpieniu. Jeżeli zaś w ciągu miesiąca nie odeśle deklaracji do urzędu stanu cywilnego, wstąpienie do organizacji wyznaniowej staje się prawnie skuteczne licząc od dnia złożenia deklaracji w urzędzie państwowym (§ 9). Zgłoszenie o wstąpieniu do stowarzyszenia, które nie zawiera warunków określonych przez rozporządzenie namiestnika Rzeszy z dnia 13. IX. 1941 r., oddala urzędnik stanu cywilnego podając uzasadnienie. Na wniosek odrzucony przez zrzeszenie religijne odpowiada urząd stanu cywilnego $(\$ 10)$.

Rozporządzenie z dnia 13.IX. rozróżnia przynależnośc prawną i udział w nabożeństwach, w ogóle „urządzeniach" (,Veranstaltungen”) organizowanych przez zrzeszenie religijne. Osoby, które nie posiadają prawnej. przynaleźności mogą uczestniczyć w „urządzeniach o charakterze wyznaniowym" (§ 11).

Uprawnienia członkowskie traci się: przez utratę zamieszkania w Kraju Warty, przez wystąpienie z związku religijnego, przez śmierć oraz przez wydalenie zgodnie $z$ postanowieniami statutu (§ 12). Sprawie wystąpień poświęca więcej miejsca rozporządzenie $z$ dnia 13.1X. Jest to obowiązek osobisty, który może być dokonany pisemnie lub ustnie, jednaik zawsze przed urzędnikiem stanu cywilnego miejsca zamieszkania. Niektóre kategorie ośbb jak czlonkowie służby czynnej Wehrmachtu, formacji zbrojnych SS, organizacji politycznych podczas specjalnych akcji, Reichsarbeitsdienstu, organizacji Todt i innych mogą złożyć oß́wiadczenie o wystąpieniu w miejscu zatrzymania się ( $\S 13$ ust. 1). Wystąpienie jest prawnie skuteczne z dniem zlożenia oswiadczenia przed urzędnikiem stanu cywilnego ( $\$ 13$ ust. 3). Urząd stanu cywilnego wystawia zaświadczenie o wystąpieniu i zawiadamia o tym zainteresowane zrzeszenie religijne ( $\S 14$ ).

Rozporządzenie $z$ dnia $13.1 X .1941 \mathrm{r}$. wyraźnie nie podnosi zagadnienia osobowości prawnej części składowych stowarzyszeń religijnych, które stanowią czlon organizacji ustrojowej związku religijnego, np. parafii, gmin kościelnych $i$ innych instytucji. Zgodnie z $\S 1$ tegoż rozporządzenia osobowosć prawną posiada tylko stowarzyszenie jako ca-

${ }_{25}$ Tamże. 
łość. Jak wyraźnie określa zarządzenie wykonawcze z dnia 19.XI.1941 r.. wszystkie podporządkowane w ramach stowarzyszenia osoby prawne utraciły samoistną osobowosć prawną ${ }^{26}$.

\section{Stosunek rozporządzenia $\mathrm{z}$ dnia $13.1 X .1941 \mathrm{r}$. do prawa kanonicznego}

Rozporządzenie z dnia 13.IX.1941 r. właściwie nie daje podstaw do sformułowania $w$ ten spośb zagadnienia, ponieważ okupacyjny prawodawca pominął zupełnym milczeniem stosunek do prawa kościelnego. Podobny stosunek znajduje się $w$ oficjalnych wypowiedziach przedstawicieli niemieckich władz państwowych, którzy z calym naciskiem podkreślali, że nowe rozporządzenie normuje porządek prawny nie Kościoła katolickiego, lecz osoby prawnej Kościoła w państwie w stosunku do stanu z dnia 1.IX.1939 r., czyli sytuację prawną Kościoła w Kraju Warty. W rozmowach, które prowadzono $w$ związku z redakcją statutu, stanowiących wynik działania rozporządzenia, nigdy nie postawiono interesującego nas zagadnienia jako zasadniczego przedmiotu konfrontacji. Referent spraw kościelnych, jeżeli wysuwano rozbieżności pomiędzy prawem kanonicznym a treścią rozporządzenia, oddalał tę sprawę motywując, że są to zagadnienia wewnątrzkościelne. Zatem wola prawodawcy o stosunku do prawa kanonicznego nie została formalnie wyrażona, lecz zawiera się $w$ treści przepisów rozporządzenia i $z$ tego punktu widzenia można rozpatrywać treść aktu w stosunku do prawa koscielnego.

Rozporządzenie niamiestnika Rzszy powołuje do istnienia jedną osobę prawną: Kościót Rzymskokatolicki Narodowości Niemieckiej w Kraju Warty. Jest to osoba prawna prawa prywatnego. Posiada zatem.zdolnosć prawną w zakresie prawnocywilnym ${ }^{27}$.

Prawo kanonicznie rozróżnia osoby fizyczne i moralne przyznając im osobowość prawną. Osoba moralna i osoba prawna są określeniami synonimicznymi występującymi zamiennie w Kadeksie Prawa Kanonicznego. Osoby moralne dzielą się na kolegialne i niekolegialne. Do pierwszej grupy należą osoby fizyczne zrzeszone $w$ jednostke prawną, do drugiej instytucje i zakłady dla celów użyteczności publicznej. Osobowość prawną zatem posiadają Kosciół katolicki, Stolica Apostolska, diecezje, koscioly, seminaria, beneficja, zakłady, szpitale, kapituly, zakony, klasztory. Zródłem osobowości prawnej jest $w$ odniesieniu do Kościoła katolickiego i stolicy Apostolskiej pozytywne ustanowienie Boże, w odniesieniu do niższych osób prawnych ustanowienie kompetentnej władzy kościelnej lub samego prawa kanonicznego. Zdolnosć prawną kościelnych osób prawnych uznawal zarówno konkordat pol-

${ }^{26}$ Tamże, 73.

27 Zob. przypis 16. 
ski z 1925 r. i konkordat niemiecki z 1933 r. Zatem rozporządzenie z dnia 13.IX.1941 r. ignoruje pluralizm kościelnych osób prawnych. Żadną miarą nie można zastosować do Kościoła katolickiego $\S 5$ rozporządzenia z dnia 13.IX.1941 r. o wygaśnięciu osobowości prawnej, ponieważ Kościół jako osoba prawna jest wieczysta. Osoby prawne niższego rzędu mogą byé tylko zniesione, jeżeli zostaną zastosowane wymogi kanoniczne.

Rozporządzenie z dnia 13.IX.1941 r. nazywa zrzeszenie katolików niemieckich Kosciołem rzymskokatolickim. Pomiędzy zakresem tresci zrzeszenia a pojęciem Kościoła rzymskokatolickiego istnieją istotne różnice. Zrzeszenie jest cywilno-prawną formą egzystencji w Rzeszy Niemieckiej. Jest to forma swoistego rodzaju, pod szczególnym nadzorem czynników państwowych, ograniczona w uprawnieniach $w$ większym stopniu niż zwykłe stowarzyszenia prywatne. Pojęcie Kościoła zaś czerpiemy $z$ dogmatyki i prawa kanonicznego. Pojęcie prawne Koscioła najlepiej określa opis Bellarmina, który zawiera następujące elementy: społecznośc wyznająca tę samą wiarę, uczestnicząca w tych samych sakramentach, podporządkowana prawowitym pasterzom, szczególnie papieżowi. Wiadomo jednak, że do pojęcia Kościoła należy także jego struktura wewnętrzna, nadprzyrodzona: obecnosć Chrystusa jako jego głowy, Ducha Sw., - jako jego duszy, łaska Boża. Zatem to, co stanowi treść rozporządzenia $z$ dnia 13.IX.1941 r. nie może być określone nazwą: Kosciół rzymskokatolicki.

Rozdział narodowościowy, który sankcjonuje rozporządzenie, jest obcy przepisom prawa koscielnego. Organizacja Koscioła ma zasadniczo charakter terytorialny i przelożeni kościelni wykonują uprawnienia na określonym obszarze. Prawo kościelne nie zna organizacji ponadpararafialnej, której podstawę stanowiłby język lub przynależność narodowa. To samo prawo przeciwstawia się utworzeniu parafii narodowosciowych, językowych. Do erygowania takich parafii jest potrzebny indult Stolicy Apostolskiej (can. $216 \S 4$ ).

Istotne róźnice istnieją $\mathrm{w}$ odniesieniu do przynależności do Kościola Katolickiego i okupacyjnego zrzeszenia katolikow. Warunkiem przynależności do Kościola katolickiego jest chrzest $z$ wody ważnie przyjęty. Od tego momentu osoba fizyczna staje się podmiotem praw i obowiązków, które mogą być jedynie ograniczone zdolnością do czynności prawnych. Wiek i zamieszkanie tylko warunkują zdolność do działania. Przynależność do Kościoła właściwie nigdy nie wygasa, chociaż na skutek istniejącej zawady (,obex”) czy nałożonej cenzury kościelnej może nastąpić w znaczym stopniu ograniczenie w prawach czlonka. Zatem ani pełnoletność, ani deklaracja o wstąpieniu nie warunkują przynależności do Kościoła.

W Kościele władzę zwierzchnią spełniają urzędnicy kościelni, którzy tworzą hierarchię. Hierarchia jurysdykcyjna jest $z$ ustanowienia Bożego i kościelnego. Powoływania wyższej hierarchii dokonuje papież. Po- 
jęciami: „zarząd”, „członek zarządu” nie posługuje się prawo kościelne na oznaczenie terytorialnych władz Kościoła. Sposób powoływania do „zarządu" pozostawia rozporządzenie z dnia 13.IX.1941 r. do uregulowania przez statut, jednakże jednostronnie wprowadzając „klauzulę polityczną" nie tylko stawia warunek powołania do „zarządu", lecz również przewiduje możliwość zastosowania jej po objęciu urzędu. Korzystanie $z$,klauzuli" należy wyłącznie do namiestnika Rzeszy.

\section{Stosunek Stolicy Apostolskiej do sytuacji prawnej}

Wiadomość o opublikowaniu rozporządzenia z 13.IX.1941 r. zostala przekazana $z$ Poznania do nuncjusza apostolskiego $\mathrm{w}$ Berlinie 14.IX. Nuncjusz otrzymał tekst zarządzenia, który przywiózł pewien niemiecki zakonnik. Informator domagał się instrukcji $w$ sprawie dalszego postępowania katolików $w$ obliczu sytuacji, jaka powstała na skutek wejścia $w$ życie nowego prawa wyznaniowego. Nuncjusz nie mógł udzielić odpowieđzi, ponieważ sam uważał za konieczne $\mathrm{z}$ uwagi na ważność zagadnienia zwrócić się do swoich wladz nadrzędnych po odpowiednie instrukcje. Bp Dy mek nie skontaktował się zaraz z nuncjuszem. Byto to spowodowane ograniczeniem $w$ zakresie wolnosci osobistej i obawą przed represjami lokalnych władz, które mogłyby wyciągnąć konsekwencje za samowolne kontaktowanie się i informowanie nuncjusza berlińskiego. Tego samego dnia abp Orsenigo przekazal do Rzymu tekst rozporządzenia namiestnika Rzeszy prosząc usilnie kard. Ma1 i on e 0 instrukcje 28 . Odpowiedź z Watykanu została wysłana telegraficznie 20.IX. Kard. M a gli o n e nakazal nuncjuszowi wniesć ostry protest do władz Rzeszy, katolików zaś Kraju Warty polecil zawiadomić, że mają również protestować przeciw rozporządzeniu a nawet stawiać opór, jeżeli w wyniku działania rozporządzenia zostanie zniesiona hierarchia kościelna i wykluczona będzie przynależnośc do kościoła osobom niepełnoletnim ${ }^{29}$. 29.IX. abp Orsenigo złożył notę werbalną w Urzędzie Spraw Zagranicznych, w której zaprotestowal przeciw jednostronnemu zniesieniu struktury organizacyjnej Kościola (diecezji i parafii) i jego kanonicznej hierarchii przez rozporządzenie - związkach religijnych, domagając się jego anulowania ${ }^{30}$. Skutecznosć interwencji watykańskiej była $z$ góry wątpliwa, bowiem $\mathrm{Gr}$ e ise r odrzucał wszelką ingerencję $z$ zewnątrz. Jednocześnie nuncjusz zawiadomil niemieckich katolików, że nie wolno im jako osobom prywatnym nawiązać rokowań $z$ przedstawicielami władz okupacyjnych.

28 Actes et documentes du Saint Siège relatifs à la seconde guerre mondiale v. III Città del Vaticano 1967 (skrót: ADSS) dok. 305 s. 456457. Zakonnik nie jest zidentyfikowany.

29 Tamze, dok. 308, s. 461.

so Tamże, s. 471 (aneks). 
akcentując zas rolę dotychczasowej hierarchii nuncjusz zażądał od wikariusza generalnego archidiecezji poznańskiej bpa $\mathrm{Dy} \mathrm{m} \mathrm{k}$ a raportu sytuacyjnego oraz opracowania projektu postępowania w okolicznoscich wy.wołanych rozporządzeniem namiestnika Rzeszy. Sytuacja pod koniec września stawała się coraz bardziej nagląca. Eączność pomiędzy nuncjuszem berlińskim a poznańskim osrodkiem koscielnym była bardzo utrudniona, bowiem odbywała się $w$ warunkach zakonspirowanych. Katolicy niemieccy niecierpieli się, domagając się praktycznych wskazań. Chodziło im także o to, aby Stolica Apostolska wydelegowala swego reprezentanta do prowadzenia rozmów z przedstawicielami władz politycznych ${ }^{31}$. Dnia 26. IX wikariusze generalni dwóch archidiecezji wielkopolskich gnieźnieńskiej i poznańskiej ks. Edward van B lericq i bp Walenty Dymek wystosowali memorial do Pi us a XII ${ }^{32}$ w sprawie sytuacji kościelnej w Kraju Warty akcentując w nim wyjątkowo poważne polożenie Kościola, które uległo jeszcze dalszemu pogorszeniu na skutek rozporządzenia o strukturze prawnej Kościoła. Autorzy pisma podkreślali, że wszyscy biskupi wielkopolscy, poza sufraganem poznańskim, zostali wydaleni. Znajdują się na wygnaniu, a nawet w przypadku bpa Michala Kozala w obozie koncentracyjnym w Dachau. Usunięto z Kraju Warty $3 / 4$ kleru, który przebywa na wygnaniu lub jest więziony w obozach. Nie ma prawie zakonów i domów zakonnych. Członkowie kongregacji zakonnych znajdują się w obozach, zostali wysiedleni, pracują w swieckich zawodach. Przedstawiwszy istotne zasady nowego prawa, wspomniani autorzy stwierdzili, że jakikolwiek opór przeciwko rozporządzaniu namiestnika spowoduje niebezpieczeństwo zamknięcia czynnych jeszcze kościołów, aresztowania reszty duchowieństwa $i$ w konsekwencji zupelne zlikwidowanie duszpasterstwa ${ }^{33}$. W tej sytuacji wikariusze generalni skierowali zapytanie, czy Stolica Apostolska aprobuje zorganizowanie życia koscielnego w ramach wymogów rozporządzenia namiestnika Rzeszy, prosząc jednocześnie, jeżeli odpowiedź wypadnie pozytywnie o rozdzielenie jurysdykcyjne według zasad narodowosciowych. Równoczesnie kapłani narodowosci niemieckiej rezydujacy w Poznaniu: ks. kan. dr Albert S t e u e r, ks. kan. dr Józef $\mathrm{Pa}$ e $\mathrm{ch}$ i O. Hilarius Breitinger skierowali imieniem wszystkich księży niemieckich w Kraju. Warty i w porozumieniu $z$ polskimi prałatami osobny memorial do Pius a XII poswięcony duszpasterstwu niemieckiemu oraz postulaty wynikające z sytuacji kościelno-politycznej wytworzonej rozporządzeniem namiestnika Rzeszy. Duszpasterstwo niemieckie, jak stwierdzają autorzy pisma, nie jest dostatecznie zorganizowane $i$ nie jest $w$ stanie zaradzić nawet najbardziej pilnym potrzebom. Przyczyny tego stanu tkwia w braku księży niemieckich i słabo zorganizowanej sieci opieki religij1941.

31 Tamże, dok. 313, s. 470, abp Orsenigo do kard. Maglione $1 \mathrm{X}$ 941.

2 Tamże, dok. 315 (aneks), s. 474-476. 
nej nad Niemcami. Ten stan duszpasterstwa oraz inne ciosy, które otrzymuje Kosciol katolicki, są zdaniem księży niemieckich, częsciowo wynikiem zależności niemieckich duszpasterzy od polskich władz diecezjalnych. Bylyby one do uniknięcia, gdyby Stolica Apostolska już wcześniej zerwała zależność duszpasterstwa niemieckiego od polskich prałatów. Niemiec wyposażony $w$ odpowiednie uprawnienia jurysdykcyjne, mógłby przeciwdziałać antykoscielnym zarządzeniom władz politycznych. Analizując istniejącą sytuację kośsielno-polityczną autorzy memoriału dochodzą do następujących stwierdzen.

1. Namiestnik Rzeszy żadną miarą nie odstąpi od zalegalizowanej formy prawnej. Konsekwentnie dążyć będzie przy pomocy nowych rozporządzeń do zniszczenia Koscioła. Jakakolwiek akcja protestacyjna $u$ wladz ministerialnych jest skazana na niepowodzenie, ponieważ namiestnik Rzeszy jest wyposażony w wyjątkowe uprawnienia. W tym stanie rzeczy przyszłość Kościoła jest uwarunkowana jego stosunkiem do rozporządzenia namiestnika.

2. Istnieje możliwość kompromisu. W ramach zasad rozporządzenia, które jest tylko prawnopaństwowa formą strukturalną, można będzie zagwarantować zasady koscielne $w$ odniesieniu do hierarchii $i$ jurysdykcji. Jedynie afirmując nową formę prawną umożliwi się opiekę religijną na okres wojny.

3. Przyjmując osobowośc prawnoprywatną Kościół utraci przywileje, które posiadł jako stowarzyszenie prawnopubliczne. Przyjęcie nowej formy prawnej nie oznacza wcale zrezygnowania $z$ tych przywilejów. W przeciwnym razie Koscioł będzie w ogóle bez żadnej formy prawnej. Będzie mogł nadal protestować przeciwko pozbawieniu go przez państwo publicznych uprawnień.

4. Z przyjęciem nowej formy prawnej łączą się korzysci dla duszpasterstwa w tym sensie, że bariera prawna ochroni Kosciół przed samowolą lokalnych władz.

5. Nowa forma prawna nie oznacza normlizocji stosunków, lecz tylko srodek przejściowy na okres wojny.

Biorąc pod uwage powyższe motywy reprezentanci niemieckich katolików prosili Piusa XII:

1. o wniesienie protestu do najwyższych władz III Rzeszy przeciwko pozbawieniu Kościoła dotychczasowych uprawnień,

2. upoważnić niemieckiego księdza wyposażonego w uprawnienia administratora apostolskiego do pertraktowania $\mathrm{z}$ władzami okręgu w sprawie statutów, jakich domaga się rozporządzenie. Celem statutów będzie usunięcie ograniczeń pracy duszpasterskiej.

3. nakazem chwili jest pośpiech, ponieważ spodziewać się można, że

${ }^{33}$ "Decretum allegatum est in pleno vigore et omnis conatus illud non observandi inducit immediatum periculum, quod claudantur eccle- 
namiestnik Rzeszy $w$ najbliższym czasie stosując nowe represje przystąpi do dzieła zniszczenia Kościola ${ }^{34}$,

Pomiędzy memoriałami polskich wikariuszów generalnych a księży niemieckich istnieje róṅnica. Polscy prałaci patrzą bezradnie w przyszłosć. Ta ostrożnosé i zdanie się na Stolice Apostolską byla także wynikiem statusu, w jakim znalazl się „Kosciól polski”. Niemiecka organizacja kościelna mocą rozporządzenia namiestnika otrzymała już osobowosć prawną, podczas gdy „Kosció polski” byl tylko potencjalnym podmiotem prawnym i hipotetycznym partnerem pertraktacji z wladzami politycznymi. Obydwa pisma akcentują następujące sprawy:

1. opór przeciwko rozporządzeniu byłby zgubny dla Koscioła,

2. konieczny jest jak największy pospiech w sprawie nowych przeobrażeń prawnych, aby ochronić Kościół przed stratami.

Dnia 6.X. dokumenty z Poznania dotarły do Berlina. Następnego dnia nuncjusz apostolski przekazal do kard. Maglion e wspomniane teksty razem $z$ raportem o sytuacji duszpasterskiej $w$ archidiecezji

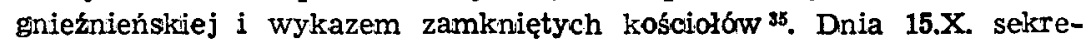
tarz stanu kard. Maglione, odpowiadając na korespondencję i doniesienia z Kraju Warty, wysłał do nuncjusza instrukcje i dyspozycje organizacyjne. Stolica Apostolska zamianuje dwóch prałatów wyposażonych w uprawnienia administratorów apostolskich, którzy będą pertraktować $w$ sprawie statusu prawnego Kościoła. Dla katolików niemieckich zostal wydelegowany ks. kan. Paech. Polska organizacja nie miala jeszcze aktualnie zwierzchnika kościelnego i reprezentanta. Ks. Pa e h miał pertraktować z władzami okręgu jako przedstawiciel katolików niemieckich. Nie wolno mu było powolywać się na autorytet Stolicy Apostolskiej. W odniesieniu do tego zastrzeżenia miała bye tak daleko zachowana ostrożność, że kardynal sekretarz stanu polecił ks. Paechowi unikać nawet pozorów autoryzacji Stolicy Apostolskiej. W statutach należało zawrzeć formalną deklarację stwierdzającą wyraźnie:

1. że katolicy niemieccy pozostaną podległymi hierarchii kościelnej i w lączności ze Stolicą Apostolską,

2. że w wewnętrznym ustroju stowarzyszenia będą się kierować zasadami prawa kanonicznego.

Od tych warunków nie mogli odstąpić katolicy. Jeżeli zaś te gwarancje zostałyby odrzucone, mieli nałożony $w$ sumieniu obowiązek formalnie wystąpic ze stowarzyszenia. Wladze watykańskie zastrzegły sobie równieź nadzór nad trescią statutów, które mialy byé nadesłane do Rzymu przed wręczeniem ich namiestnikowi Rzeszy.

Istotny wplyw na decyzje Stolicy Apostolskiej - kard. Maglio-

siae, quae restant adhuc apertae, ac incarcerentur sacerdotes adhuc liberi ac denique omnis cura animarum vetetur". Tamże, s. 475.

34 Tamze, s. $476-479$.

35 Tamże, dok. 315 , s. 473. 
ne i Piusa XII wywarly doniesienia i raporty z Kraju Warty, które podkreślały konieczność akomodacji do nowego systemu prawnego, ażeby Kościół i życie religijne ocalić przed dalszymi stratami. Ich celem było dobro dusz i zapewnienie opieki religijnej obu narodowosci. Niezależnie od decyzji i zarządzeń Stolica Apostolska nie zrezygnowała $z$ akcji protestacyjnej przeciwko polityce koscielnej Greiser a. Nuncjusz apostolski miał wnieść protest do samego Hitlera ${ }^{36}$.

\section{Skutki kanoniczne rozporządzenia z 13.IX.1941 tr.}

Rozporządzenie Gre is e r a spowodowalo Stolicę Apostolską do podjęcia tymczasowych zarządzeń $w$ sprawie struktury organizacyjnej Kosciola wielkopolskiego. Istniejący dotychczas monolit organizacyjny oparty na strukturze terytorialnej został rozdzielony na dwie rownorzędne organizacje koscielne: niemiecką $i$ polską. Był to wynik działania polityki rozdziału narodowego'na płaszczyźnie kościelnej. Wprawdzie podzial narodowosciowy jest obcy zasadom prawa koscielnego, ale możliwy do przyjęcia. Nowa struktura kościelna była ograniczona zasięgiem granic administracyjnych okręgu. Datychczasowe polskie diecezje Kraju Warty nie zostały rozwiązane, lecz ulegla tylko zawieszeniu jurysdykcja ich ordynariuszów na rzecz nowych zwierzchników kościelnych. Od momentu zadekretowania Stolicy Apostolskiej zaczęla formalnie istnieć administracja apostolska dla katolików niemieckich, która była kanonicznym odpowiednikiem stosowanego, zresztą niesłusznie przez władze polityczne, okreslenia: Koscibł Rzymsko-katolicki Narodowości Niemieckiej w Kraju Warty. W odniesieniu do polskich członków Kościoła katolickiego Stolica Apostolska wydała analogiczne zarządzenia. Został wyznaczony administrator Apostolski w osobie bp W. Dy mka, lecz polska organizacja koscielna pozostała w rzeczywistości tylko postulatem ${ }^{37}$.

86 Tamże, dok. 319 , s. $481-486$.

37 Administratorem apostolskim katolików niemieckich w Kraju Warty zostal 18 X $1941 \mathrm{r}$. ks. kanonik dr Józef $\mathrm{P}$ a e ch, po nim nominację nad administratora apostolskiego otrzymał $2 \mathrm{~V} 1942 \mathrm{r}$. 0 . Hilarius Breitinger OFM Conv. Biskup Walenty Dymek zostal mianowany administratorem apostolskim katolikow - Polakbw w Kraju Warty 9 IV 1942 r. Publikację swego stanowiska pozostawiła do uznania Stolica Apostolska nominatowi. Faktycznie bp Dymek nie wykonał dekretu Stolicy Apostolskiej. Złożyło się na to wiele przyczyn: brak pełnej wolności osobistej nominata, brak porozumienia w sprawie statusu prawnego "polskiego" Kosciola; Bormann i Greiser zamierzali „powolać” do istnienia stowarzyszenie polskich katolików, lecz nie podjęli decyzji o realizacji tego zamierzenia; wydaje się, że i sam nominat preferowal odroczenie promulgacji swego dekretu. 


\section{Statuty niemieckich katolików}

Rozporządzenie z dnia 13.IX.1941 r. nałożyło obowiązek przygotowania statutów przez obdarzone osobowoscią prawną społeczności wyznaniowe. Biorąc pod uwagę $\S 3$ rozporządzenia traktujący o treści statutów, problematykę-organizacyjną pozostawiono. do ustalenia poszczgólnym związkom religijnym. Dla Koscioła istotny był zakres samodzielności, który zabezpieczą statuty zatwierdzone przez namiestnika Rzeszy. W statutach miała się wyrazić konkretna forma organizacji.

Dla władz koscielnych redakcja statutów była ważnym zagadnieniem. Rozporządzenie namiestnika pomijalo milczeniem stosunek powołanej do życia organizacji do Kościola Katolickiego, do prawa kanonicznego, do hierarchii kościelnej. Wciąż wyłaniało się istotne pytanie, czy władze hitlerowskie nie zechcą utożsamiać utworzonej organizacji katolików z Kosciolem katolickim. Władze koscielne były przekonane, że od redakcji statutów może zależeć przyszłość Kościola w Kraju Warty, a nawet losy Koscioła w całej Rzeszy. Natomiast druga strona, reprezentanci wladz okupacyjnych, nie chcieli ujawniac intencji, a przede wszystkim pilnowali, aby statuty nie były próbą wewnętrznego rozsadzenia rozporządzenia $z$ dnia $13.1 X$.

W stosowaniu prawa nadzoru da się wyodrębnić 3 fazy, jeżeli pominie się stosunek do katolików - Polaków.

1. w pierwszym okresie lokalne władze hitlerowskie zamierzały uznanym związkom religijnym narzucić formę statutów,

2. $w$ drugiej fazie na zalecenie kancelarii monachijskiej NSDAP zmieniono taktykę. Poznańskie władze okupacyjne miały pisemnie zawiadomić uznane Kościoly, jakie muszą być dokonane modyfikacje $w$ statutach, aby mogły uzyskać aprobatę państwa ${ }^{38}$,

3. w ostatnim stadium przesłano projekt wzorcowy, który po akceptacji przez przedstawicieli związku religijnego, władze okupacyjne były gotowe zatwierdzić ${ }^{38}$.

Różnica pomiędzy poszczególnymi fazami była tylko natury formalnej, bowiem na każdym etapie władze okupacyjne dysponowały poważnym narzędziem nacisku na płaszczyźnie finansowej: zatwierdzenie ordynacji skkadkowej było uwarunkowane zatwierdzeniem statutu.

Kościól rzymskokatolicki Narodowości Niemieckiej w okręgu Rzeszy Kraj Warty już w grudniu 1941 r. przystąpił do przygotowania redakcji statutów. Lokalne władze koscielne, administratorzy apostolscy najpierw kanonik Józef $\mathrm{Paech}$, a od maja $1942 \mathrm{r}$. O. Hilary Breitinger korzystali z pomocy innych osrodkow kościelnych. Np. na konfe-

38 AGK 584 (Z) VIII/III, 114-115, protokót konferencji szefów urzędów Tajnej Policji Państwowej Kraju Warty $w$ Inowrocławiu 19 XI $1942 \mathrm{r}$.

39 Archiwum Archidiecezjalne we Wroclawiu (skrót: AAWr) I A 25 w 49 pismo urzędu namiestnika Rzeszy do Kościola rzymsko-katolickiego narodowości niemieckiej 23 IV 1943. 
rencje w dniach od 15-19.XII.1941 r. w Poznaniu poswięconą sprawom statutu zaproszona prof. Köh le r a z Gdańska. Na tę samą konferencje kan. $\mathrm{Pa}$ e $\mathrm{ch}$ zaprosił przedstawiciela ze środowiska prawnokościelnego Wrocławia ${ }^{40}$. Jego następca $O$. Breitinger zasięgal opinii we wrocławskim Instytucie Administracji Koscielnej i Gospodarki Finansowej.

Kościelny projekt statutu został przygotowany razem z pismem załącznikowym dnia 25.IV.1942 r. Pismo załącznikowe jest ciekawym dokumentem, który zawiera zastrzeżenia w stosunku do wyznaniowej osoby prawnej i konfrontacje węzlowe problemy koscielne $z$ nowym porządkiem prawnym ${ }^{41}$. Po doręczeniu projektu statutu referent spraw kościelnych urzędu namiestnika Rzeszy dr Birk na konferencji odbytej 23.VI.1942 r. przedstawił stronie kościelnej zastrzeżenia dotyczące przedstawionego projektu statutu. Niemieckich katolików reprezentowali: administrator apostolski O. H. B r e it in ger oraz generalny dyrektor Tauche. Głownym przedmiotem konferencji była nazwa katolickiej osoby prawnej, w szczególnosci termin „Kościól”, stosunek zarządu związku do jurysdykcyjnego przełożonego kościelnego oraz szereg zagadnień szczególowych, między innymi cel związku, przynależnoscc. Zastrzeżenia referenta spraw koscielnych miały wejśc $w$ formie poprawek do nowej redakcji statutu. Tresć konferencji notowała stenotypistka, stronie kościelnej nie udostępniono protokółu ${ }^{42}$. Dnia 11.IX. odbyła się jeszcze jedna konferencja poswięcona sprawie statutu. Dnia 15.IX. administrator apostolski O. Breitinger przedstawil koscielny punkt widzenia $w$ piśmie skierowanym do namiestnika Rzeszy. O. B ret in ger poruszył w nim następujące sprawy: nazwę związku, jego cel, stosunek czlonków związku do Kościoła katolickiego, wykładnię § 11 rozporządzenia $z$ dnia 13.IX. o udziale nieczłonków w kulcie religijnym oraz ustanowienie zarządu związku ${ }^{43}$. Zresztą ta problematyka byla zawsze obiektem spornym.

Dnia 23.IV.1943 r. zostal opracowany przez wladze okupacyjne projekt statutu, doręczony Kościolowi dokladnie w rocznicę przygotowania projektu kościelnego. Analogicznie do projektu kościelnego jest zaopatrzony $w$ pismo zalącznikowe, które jest odpowiedzią namiestnika Rzeszy na pismo kościelne z $25 . I V 1942$ r. ${ }^{44}$.

Projekt statutów: katolików niemieckich i władz okupacyjnych oraz dyskusja nad sformułowaniem zawartosci 45.

\footnotetext{
40 Tamże, ks. P a e c h do kard. Bertrama 8 XII 1941.

41 Tamże.

42 Tamże, sprawozdanie $z$ konferencji z dnia 23 IX 1942.

43 Tamże, o. B r e it inger do namiestnika Rzeszy 15 IX 1942 r.

44 Tamże.

45 Projekt statutu katolików niemieckich znajduje się w: AAWr I A $25 \mathrm{w}$ 49; projekt statutu wladz akupacyjnych znajduje się w cytowanym wyżej miejscu. Treść rozmów pomiędzy przedstawicielami katolików niemieckich a władzami okupacyjnymi opieram na sprawozda-
} 


\section{projekt katolików nie mieckich}

(25. IV. 1942 r.) projekt wladz

o k u p a c y j $\mathbf{n}$ y $\mathbf{c h}$

(23. IV. 1943 r.)

„Statut Kościelnej Korporacji nie- „Statut Kościola rzymskokatolicmieckich katolikow w Kraju kiego Niemieckiej Narodowości Warty". w okręgu Rzeszy Kraj Warty".

Pominięcie nazwy Kościót i wprowadzenie terminu korporacja odczytal dr Birk jako chęć przeciwstawienia Kościoła katolickiego związkowi religijnemu. Zatem zarzucil stronie kościelnej, że nie chce się posługiwać terminami występującymi w rozporządzeniu: Kościól katolicki i związek religijny. Władze państwowe bowiem stoją na stanowisku, że wyznaniowa osoba prawna wypełnia funkcje, które wykraczają poza ramy wewnątrzorganizacyjne i dlatego musi pozostać „prawna" nazwa: Kościót. Referent spraw kościelnych przypomniał, że zastosowanie terminu „Kościól” nie leżało w zamiarach niemieckich władz, lecz zostało wprowadzone na życzenie kościelnych wladz katolickich i protestanckich. Strona katolicka odrzuca zarzut twierdząc, że wprawdzie jest to zgodne $z$ prawdą, ale istniały zupełnie inne okoliczności. Sprawa ta była postawiona $w$ związku $z$ rozmowami na temat ordynacji skladkowej, kiedy jeszcze nie zostały ujawnione plany o utworzeniu nowej osoby prawnej. Kiedy jednak ukazało się nowe rozporządzenie o wyznanionych osobach prawnych, można już było się przekonać, że nazwa Kościól nie jest odpowiednia dla nowoutworzonej osoby prawnej. Dr Bir k wyjaśnił, że termin Kosciól w rozporządzeniu z dnia 13. IX. występuje w zupełnie nowym znaczeniu, które nie jest adekwatne $\mathrm{z}$ dotychczasowym zakresem treści.

Strona katolicka zdecydowanie trwała na stanowisku, że nazwa Kosció katolicki nie może byé stosowana w odniesieniu do osoby prawnej. Uzasadnienie podawała następujące: Zastosowanie nazwy Kosciót w omawianym przypadku przeciwstawia się istocie związku, może być źródłem błędów i zniepokojenia, wreszcie nazwa „Kościół” może robić wrażenie, że chodzi o korporację prawnopubliczną. Dalej nieodpowiednia jest również nazwa „związek religijny" („Religionsgesellschaft”). Ten termin jest zastosowany $w$ prawie panstwowym, jak i codziennym jezyku. Jest to pojęcie szersze, aniżeli nazwa Kościót. Nieodpowiedni, ponieważ wywoluje nieporozumienia. Natomiast do przyjęcia są nazwy: korporacja („Körperschaft”) albo zrzeszenie, stowarzyszenie (,Verein:gung"). Termin korporacja stosuje się do związków prawnopublicznych i prawnoprywatnych. Nazwa zrzeszenie jest zgodna z rozporządzeniem. Gdy idzie o sciślejsze określenie terminu, bardziej trafna jest nazwa

niach o. Breitingera $\mathrm{z}$ dnia 23 VI 1942 oraz $\mathrm{w}$ piśmie skierowanym do namiestnika Rzeszy z 15 IX 1942. Pisma te znajduja się w cytowanym wyżej zespole archiwalnym. 
Kościelne zrzeszenie (kirchliche Vereinigung) aniżeli Religijne zrzeszenie (religiöse Vereinigung). Biorąc powyższe pod uwage $\mathrm{O}$. Breitinger prosil namiestnika Rzeszy o zatwierdzenie w statucie nazwy kościelne zrzeszenie, a $\mathrm{w}$ ostatecznym razie zrzeszenie religijne. Prawdopodobnie wladze państwowe unikały wyrażenia korporacja $\mathrm{z}$ dwóch powodów:

1. rozporządzenie $\mathrm{z}$ dnia 13. IX. zadecydowało o nazwie „Kościót”, 2. termin „korporacja” zbyt silnie kojarzy się ze związkiem prawnopublicznym.

\begin{tabular}{|c|c|}
\hline $\begin{array}{l}\text { „Na mocy rozporządzenia na- } \\
\text { miestnika Rzeszy w Kraju Warty } \\
\text { z dnia 13. IX. } 1941 \text { r. o związkach } \\
\text { religijnych i stowarzyszeniach re- } \\
\text { ligijnych w okregu Rzeszy Kraj } \\
\text { Warty (Verordnungsblatt des } \\
\text { Reichsstatthalters im Warthegau } \\
\text { Nr } 30 \text { z 13. IX. 1941) została usta- } \\
\text { nowiona dla niemieckich katolików } \\
\text { w Kraju Warty osoba prawna } \\
\text { prawa prywatnego. Zgodnie z } ~ \\
\text { ust. } 1 \text { tegoż rozporządzenia otrzy- } \\
\text { muje ona następujący statut”. }\end{array}$ & $\begin{array}{l}\text { „Na mocy rozporządzenia } \\
\text { o związkach religijnych i stowa- } \\
\text { rzyszeniach religijnych w okręgu } \\
\text { Rzeszy Kraj Warty z dnia 13. IX. } \\
1941 \text { r. (Verordnungsblatt des } \\
\text { Reichsstatthalters im Warthegau } \\
\text { s. 463) na miejsce istniejących } \\
\text { 1. IX. } 1939 \text { r. osób prawnych Ko- } \\
\text { ścioła Rzymskokatolickiego otrzy- } \\
\text { mała osobowoś prawną prawa } \\
\text { prywatnego jedna osoba prawna } \\
\text { Rzymskokatolicki Kościół Niemiec- } \\
\text { kiej Narodowości w okregu Rzeszy } \\
\text { Kraj Warty. Zgodnie z } \$ \text { ust. } 1 \\
\text { tegoż rozporządzenia nadaje sobie } \\
\text { to religijne stowarzyszenie nastę- } \\
\text { pujący statut”. }\end{array}$ \\
\hline
\end{tabular}

W toku dyskusji nad statutem kościelnym (wersja kościelna) dr B ir k był gotów pójść na pewne zmiany zezwalające na wprowadzenie dododatkowego wyjaśnienie o podwójnym znaczeniu terminu Kościól tzn. pojęcia prawnopaństwowego i prawnokościelnego. Treść pierwszego znaczenia mogłaby być zaczerpnięta $z$ rozporządzenia $z$ 13. IX. $1941 \mathrm{r}$. mianowicie 2 zdanie $\mathrm{w} \S 2$ ust. 1. Zaproponowal zatem: Na mocy rozporządzenia $z$ dnia 13. IX. 1941 r. o ... na miejsce istniejących 1. IX. $1939 \mathrm{r}$. osób prawnych Kościoła Rzymskokatolickiego otrzymał osobowość prawną prawa prywatnego Kościól Rzymskokatolicki Narodowosci Niemieckiej w okręgu Rzeszy Kraj Warty". To sformułowanie znalazło się $w$ wersji statutu władz okupacyjnych. Dopiero po tym fragmencie można wprowadzić wyjasnienie o podwójnym znaczeniu pojęcia Kościót. 


\section{„§ 1. Nazwa i siedziba}

1. Ustanowiona na mocy rozporządzenia z dnia 13. IX. $1941 \mathrm{r}$. osoba prawna prawa prywatnego dla rzymoskokatolickich chrześcijan niemieckiej narodowości Kraju Warty przybiera nazwę: „Koscielna Korporacja Niemieckich Katolik 6 w w Kraju Warty - w poniższych paragrafach nazwana krotko „Korporacja”.

2. Jej siedzibą jest miasto Poznań".
„§ 1. Nazwa i siedziba

1. Stowarzyszenie religijne przybiera zgodnie $\mathrm{z}$ rozporządzeniem z 13. IX. 1941 r. nazwę "Kosciól Rzymskokatolicki Niemiecskiej Narodowości w okręgu Rzeszy Kraj Warty.

2. Jego siedzibą jest miasto Poznañ".

Uwagi odnoszące się do dyskusji nad nazwą mają i tu zastosowanie.

"§ 2. Cel

Korporacja ma za cel stworzenie Kościołowi rzymsko-katolickiemu prawnocywilnej podstawy do wypełnienia zađań kultowych i duszpasterskich wobec niemieckich katolików w Kraju Warty, szczególnie przez dostarczenie środków i zarząd majątkiem".
„§ 2. Cel

Stowarzyszenie religijne jako istniejąca prawnie organizacja dla katolików niemieckiej narodowosci ma za zadanie $w$ ramach statutu i przepisów państwowych:

1. troszczyć się o wymagane funkcjonowanie instytucji kościelnych,

2. starać się o niezbędne srodki,

3. dysponować i zarządzać majątkiem koscielnym zgodnie z określonym celem".

Dr Birk zakwestionowal sformulowanie $\S 2$ o celach związku. $\mathrm{Z}$ wersji kościelnej należy usunąc następujące zwroty: Kosciót rzymskokatolicki oraz fragmenty mówiące o zadaniach kultowych i duszpasterskich. Te sformulowania bowiem ujmuja zadania wewnątrzkościelne. Dr Birk zaproponowal zmiane $\S 2$ i dostosowanie go do projektu przekazanego już kościołom protestanckim. O. Breitinger zgodził się na przeredagowanie $\$ 2$ i przedstawil projekt $w$ następującej wersji: „Zrzeszenie kościelne ma za zadanie w ramach statutu i przepisów państwowych: 1. troszczyć się o funkcjonowanie instytucji koscielnych, które potrzebuje rzymskokatolicki Kościół, aby wypełnić swoje zadanie w Kraju Warty, 2. dostarczyć środków niezbędnych do wypełnienia jego zadań, także zarządzać i dysponować nabytym majątkiem zgodnie $z$ jego przeznaczeniem". 
„§ 3. Przynależność

1. Członkami korporacji stali się razem $z$ uprawomocnieniem sie rozporządzenia $z$ dnia 13. IX. 1941 r. wszyscy pelnoletni katolicy, którzy w tym dniu poKościelna (§ 9) ma obowiazek Warty, za wyjątkiem tych osób, które 1. IX. 1939 r. posiadały niemiecką przynależność państwową, jak również Polaków.

2. Przynależność mogą nabyć wszyscy pełnoletni katolicy, którzy posiadają zamieszkanie w Kraju Warty i nie są Polakami.

3. O przyjęciu i wykluczeniu czlonka decyduje zarząd $z$ wylączeniem postępowania sądowego".
„§ 3. Przynależność

1. Członkiem stowarzyszenia może być tylko prawnie skutecznie osoba pełnoletnia i zamieszkująca Kraj Warty. Polacy nie mogą być członkami. Warunkiem przynależności jest osobiste ustne lub pisemne oswiadczenie o wstąpieniu przed urzędnikiem stanu cywilnego miejsca zamieszkania.

2. Osoby, które 13. IX. 1941 r. miały miejsce zamieszkania w okręgu Rzeszy Kraj Warty i 1. IX. 1939 r. nie posiadały niemieckiej przynależności państwowej, otrzymują prawa członków z dniem 13. IX. 1941 r., jeżeli wcześniej należaly do rzymskokatolickiego Kościoła i do tego czasu nie wystappiky.

3. Przynależność wygasa:

a. przez utrate miejsca zamieszkania w okręgu Rzeszy Kraj Warty,

b. przez wystąpienie zgodnie z przepisami państwowymi,

c. przez śmierć,

d. przez wykluczenie.

4. O przyjęciu i wykluczeniu członka decyduje zarząd $z$ wyłączeniem postępowania sądowego. Przyjęcie może być oddalone $w$ ciagu jednego miesiąca po przesłaniu deklaracji o wstąpieniu przez urzędnika stanu cywilnego.

5. Nienaruszone pozostaje wewnątrzkościelne działanie chrztu. Postanowienia ust. 1 nie wykluczają zgodnie $\mathrm{z} \S 11$ rozporządzenia $z$ dnia 13 . IX. 1941 r. udziału nieczlonków $\mathrm{w}$ obchodach o charakterze wyznaniowym". 
W dyskusji nad $\S 3$ referent spraw kościelnych polecił usunąc wyrażenie „katolicy" i zastąpić określeniem „osoby”. Ust. 2 i 3 miały być uzupełnione. Do ust. 2 należało dodać passus o nabyciu przynależności przez oświadczenie wobec urzędnika stanu cywilnego, co znalazło wyraz w wersji władz okupacyjnych statutu w ust. 1. Ust. 3 miał zyć uzupełniony klauzulą o pośrednictwie urzędnika stanu cywilnego w razie oddalenia przyjęcia. Treść tej klauzuli weszła do ust. 4 projektu rządowego. $\S 3$ mial być uzupełniony ust. 4 o warunkach utraty przynależności według sformułowania $\S 12$ rozporządzenia z 13. IX. 1941 roku. I wreszcie jako ust. 5 należało dodać: „Członkiem zarządu albo innego organu może być tylko członek stowarzyszenia religijnego”.

„§ 4. Prawa i obowiązki członków.

1. Na podstawie $\S 3$ tegoż statutu nabyta przynależność posiada tylko skutek prawny wobec Korporacji. Natomiast przyjęcie do rzymskokatolickiej spolecznosci koscielnej, to znaczy do Koscioła katolickiego założonego przez Jezusa Chrystusa dokonuje sie tylko przez sakrament chrztu. Postanowienia $\S 3$ nie wylączają zgodnie $z \$ 11$ rozporządzenia $z$ dnia 13 . IX. $1941 \mathrm{r}$. nieczlonków od udziału w obchodach o charakterze wyznaniowym. Kościół posiada prawo objąć także tych nieczłonków opieką duszpasterską.

2. Członkowie korporacji jako czlonkowie Kościoła rzymskokatolickiego podlegają papieżowi, najwyższej głowie Kościoła, ktory w zakresie swoich praw rządzi wedlug Kodeksu Prawa Kanonicznego (Codex Juris Canonici).

3. Są oni zobowiązani do swiadczenia składek zgodnie $z$ aktualnie obowiązującą ordynacją składkową.

4. Przysługuje im, zgodnie $z$ po-
"§ 4. Prawa i obowiązki czlonków.

1. Czlonkowie są zobowiązani do świadczenia składek, które stowarzyszenie religijne pobiera na podstawie Rozporządzenia o zbieraniu składek przez związki religijne i stowarzyszenia religijne $z$ dnia 14. III $1940 \mathrm{r}$. (Verordnungsblatt des Reichsstatthalters im Warthegaus. 22).

2. Czlonkom przysługuje, zgodnie $z$ poniższymi przepisami, prawo wglądu do zarządu majątkiem ich parafii. Parafialna Rada Koscielna (§ 9) ma obowiązek corocznie w miesiącu grudniu wyłożyć na okres dwóch tygodni w kancelarii parafialnej projekt budżetu parafii przewidziany na następny rok. Każdy członek stowarzyszenia religijnego może w tym okresie podniesć zastrzeżenia $w$ formie pisemnej lub ustnej wobec $\mathrm{Pa}$ rafialnej Rady Kościelnej dotyczące poszczególnych pozycji budżetu. Parafialna Rada Koscielna przedkłada sprzeciw kierownikowi Głownej Kasy Kościelnej razem $\mathrm{z}$ budżetem. 
niższymi przepisami, prawo wglądu do zarządu majątkiem ich parafii. Parafialna Rada (\$ 9) ma obowiązek corocznie w miesiącu grudniu wylożyć na okres dwóch tygodni w kancelarii parafialnej prcjekt budżetu parafii przewidziany na następny rok. Każdy czlonek korporacji może w tym okresie podnieść zastrzeżenia, w formie pisemnej lub ustnej, wobec $\mathrm{Pa}-$ rafialnej Rady Koscielnej dotyczące poszczególnych pozycji budżetu. Parafialna Rada Kościelna przedkłada sprzeciw kierownikowi Glównej Kasy Kościelnej razem $z$ budżetem.

5. Poszczególnym czlonkom nie przysługują żadne prawa w odniesieniu do majątku Korporacji. Nie odpowiadają za jej dlugi".
3. Poszczególnym członkom nie przysługuja żadne prawa $w$ odniesieniu do majątku stowarzyszenia religijnego. Nie odpowiadają za jego długi.

4. Tylko członek stowarzyszenia religijnego może należeć do jego organu".

Jeżeli $w$ sprawie nazwy stowarzyszenia $i \S 3$ przynależności do stowarzyszenia zarysowały się znaczne odrębnosci pomiędzy ineresem koscielnym a celami władz okupacy jnych, to sformulowania $\S 4$ stworzyły zasadniczą przeszkodę porozumienia się. Wladze kościelne włączyły do $\S 4$ restrykcje Stolicy Apostolskiej i gwarancje o objęciu opieka kościelno-duszpasterską katolików, którzy według rozporządzenia namiestnika Rzeszy z dnia 13. IX. 1941 r. nie byli lub na razie nie mogli być członkami stowarzyszenia religijnego. $\mathrm{Te}$ problematykę zawierają w $\S 4$ ust. 1 zdania: 1,2 i 4 . Referent do spraw kościelnych zażądał ich usunięcia $z$ statutu, oskarżającego władze koscielne, że przedstawiony projekt statutu jest próbą ataku przeciwko rozporządzeniu o związkach religijnych i stowarzyszeniach religijnych. Ponieważ niemieckie czynniki państwowe nie zgadzały się na wprowadzenie gwarancji kościelnych do statutów, argumentując, że to są sprawy natury wewnątrzkoscielnej i naruszają porządek paragrafów, o. B re it in ger wysunął rozwiązanie kompromisowe. Strona katolicka opuści gwarancje w $\S 4$, zdanie 1 i 2, jeżeli we wstępie do statutu, znajdzie się wyraźna deklaracja o charakterze korporacji, która miała mieć następujące sformułowanie: „Na mocy $\S 1$ ust. 1 rozporządzenia pana namiestnika Rzeszy o związkach religijnych i stowarzyszeniach religijnych $z$ dnta 13. IX. 1941 r., została utworzona na miejsce osób prawnych Kościola rzymskokatolickiego, które 1. IX. 1939 r. istniały w Kraju Warty, jedyna 
osoba prawna prawa prywatnego. Ma ona według $\$ 2$ ust. 1 rozporządzenia pana namiestnika przedstawic do zatwierdzenia swoj statut. Ponieważ ta osoba prawna nie jest kierowanym przez papieża jako głową, Kościolem rzymskokatolickim, który swoje sprawy porządkuje według prawa koscielnego (CIC) ${ }^{40}$, lecz tylko ma stworzyć prawnocywilne warunki w życiu państwowym dla koscielnej działalności rzymskokatolickich chrześcijan i ich kościelnej opieki w Kraju Warty, jej statut ma stworzyć tylko podstawę dla tego zakresu. To zaznaczywszy na wstępie, nadaje sobie osoba prawna ten statut". Drugim istotnym zagadnieniem była sprawa opieki duszpasterskiej katolików, którzy w rozumieniu rozporządzenia $z$ dnia 13. IX. nie byli czlonkami osoby prawnej. Zdanie 4 w $\S 4$ ust. 1 gwarantowało prawo Kościoła do działalności duszpasterskiej w stosunku do owych, „nieczlonków” osoby prawnej i prawa subiektywne tych katolików do korzystania z pomocy duszpasterskich. Te mysli znalazły wyraz we sformułowaniu statutu: „Kościol posiada prawo objąc także nieczłonków opieką duszpasterską". Referent spraw koscielnych zażądał usunięcia tégo zdania, ponieważ jest to oczywiste $i$ dlatego zbędne. O. Breitinger zwrócił się do Instytutu Administracji Koscielnej i Gospodarki Finansowej we Wroclawiu, aby zasięgnąć opinii, czy kwestionowane przez czynniki państwowe zdanie może być usunięte ze statutu. W odpowiedzi Instytutu zająl negatywne stanowisko motywując następująco: „Usunięcie ze statutu kwestionowanego stwierdzenia może prowadzić do przypuszczeń, że tym samym ma nastąpić ograniczenie działalności duszpasterskiej. Nie jest też rzeczą pewną, czy wszystkie urzędy państwowe podzielą pogląd referenta spraw koscielnych, który uważał tę rzecz za oczywistą. Jeżeli cytowane zdanie zostanie usunięte ze statutu, musi się znaleźć inny sposób zagwarantowania praw Kościoła. Może to nastąpić $w$ ten sposób, że namiestnik wyda na ten temat deklarację $w$ związku ze zatwierdzeniem statutu. Jeżeli zaś takie oświadczenie nie nastąpi, treść zdania musi pozostać w statucie". Wychodząc $z$ tej opinii O. Breitinger zaproponował następujące sformulowanie dyskusyjnego zdania: „Postanowienia $\S 3$, zgodnie z $\S 11$ rozporządzenia $\mathrm{z}$ dnia 13. IX. 1941 r., nie wyłączają nieczłonków od udziału w obchodach o charakterze wyznanionym. Wyjaśniając zauważa się, że według tego Kościół posiada prawo, także tych nieczlonków objąć opieką duszpasterską".

„§ 5. Zarząd

1. Przełożony ustanowiony dla kościelnego kierownictwa niemieckich katolikow w Kraju Warty według zasad prawa koscielnego mianuje zarząd korporacji. Nominacja może być w każdym czasie odwolana. Koscielny

\section{„§ 5. Zarząd}

1. Kompetentny duchowny jako przełożany według wewnętrznokościelnych zasad staje się zarządem stowarzyszenia religijnego, skoro tylko namiestnik Rzeszy w Kraju Warty na jego zapytanie oświadczył, że prze-

${ }^{46} \mathrm{CIC}$ - Codex Iuris Canonici. 
przełożony może również osobiście przejąć agendy zarządu.

2. Osobę zarządu należy niezwłocznie przestawic namiestnikowi Rzeszy. Jeżeli w ciągu miesiąca nie zostaną podniesione zastrzeżenia natury politycznej, tym samym uważa się za rezygnację $\mathrm{z}$ podniesienia sprzeciwu.

3. Kompetencje zarządu są następujące:

a. reprezentować korporację w postępowaniu sądowym i poza sądem (por. jednakże § 10),

b. wydać ordynację skłladkową,

c. zrealizować aktualnie obowiązującą ordynację składkową, zarządzać majątkiem, jeżeli jego zarząd nie podlega innym instytucjom korporacji (§ 9), i kantrolować zarząd majątkiem tych korporacji. Do wypelnienia tych zadań posługuje się Główną Kasą Kościelną (§ 8),

d. stać na straży interesów kościelnych.

4. Do załatwienia bieżących spraw administracyjnych zarząd może się posługiwać pełnomocnikiem, który jest przez niego mianowany".

W sprawie ustanawiania władz kościelnych znalazły wyraz w redakcjach statutu istotne rozbieżności pomiędzy władzami okupacyjnymi a przedstawicielami Kościoła. Władze kościelne wystąpiły z projektem rozdziału kompetencji kanonicznego przełożonego i zwierzchnika korporacji, który był zależny od pierwszego. Jednakże była także dopuszczalna unia personalna tych dwóch urzędów, $z$ zachowaniem prymatu władzy kanonicznej. Natomiast okupacyjne czynniki państwowe domagały się unifikacji władzy, to znaczy każdorazowy przełożony kanoniczny mial być również zwierzchnikiem stowarzyszenia religijnego. Podczas konferencji 23. VI. 1942 r. na temat kościelnej wersji statutu referent spraw kościelnych zażądał, aby w $\S 5$ połączyć treść ust. 1 i 2, propanu- 
jąc sformułowanie: „Przełożony, przewidziany dla kościelnego kierownictwa niemieckich katolików w Kraju Warty według wewnętrznokościelnych zasad, staje się zarządem, skoro tylko namiestnik Rzeszy na zapytanie oświadczył, że przeciwko jego osobie nie ma zastrzeżeń natury politycznej". O. B re it ing er zamierzał przekonsultować tę sprawę we wrocławskim Instytucie Administracji Koscielnej i Gospodarki Finansowej i skierował do niego zapytanie, czy w tresci statutu można zunifikować urząd kanonicznego przełożonego i zwierzchnika korporacji i czy można akceptować sformułowanie wysunięte przez referenta spraw koscielnych. W odpowiedzi Instytut zajął następujące stanowisko: \$ 4 rozporządzenia $z$ dnia 13 . IX. 1941 r. przewiduje, że warunkiem ustanowienia zarządu związku jest brak zastrzeżeń ze strony namiestnika Rzeszy. Zwierzchnik związku traci swoje stanowisko w momencie, kiedy staje się pod względem politycznym „persona non grata”. W zastosowaniu do poruszonej sprawy Stolica Apostolska moglaby tylko zamianować kanonicznego przelożonego, jeżeli jego kandydaturze nie sprzeciwi się namiestnik Rzeszy, podobnie miałaby się rzecz z jego odwołaniem.

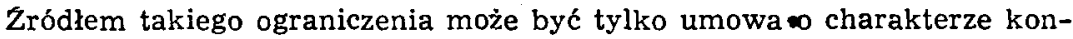
kordatu. Nawet gdyby państwo podjęło taką jednostronną decyzję, Stolica Apostolska jej nie uzna, katolikom zaś nie wolno partycypować w statucie, który ją akceptuje, ponieważ weszliby $\mathrm{w}$ kolizję $\mathrm{z}$ prawem kościelnym (kan. 218). W statucie musi być utrzymana zasada rozdziału urzędów. Jednakże przełożony kanoniczny może stać się zwierzchnikiem stowarzyszenia jako zarząd. Jeżeli zaś idzie o żądanie namiestnika Rzeszy $w$ tej sprawie, aby połączyć te dwa stanowiska, według opinii wrocławskiego Instytutu nie mają podstaw w rozporządzeniu z dnia 13. IX. 1941 r., które ustanowienie zarządu związku i sposób jego powolywania pozostawia do unormowania przez statut.

W rozmowach na temat powoływania przełożonego kościelnego okupacyjne władze państwowe stały na stanowisku, że może być tylko jeden przełożony kościelny, który jest jednocześnie zwierzchnikiem stowarzyszenia. Referent spraw kościelnych podawał następującą motywację:

1. taki stosunek wynika z rozporządzenia z 13. IX. 1941 r.,

2. powoływanie kanonicznego przełożonego, który jest "zarządem" stowarzyszenia, powinno dokonywać się według norm wewnętrznokoscielnych,

3. nie można dopuścić do rozdziału urzędów, ponieważ zarząd stowarzyszenia stałby się uległym narzędziem kanonicznego przełożonego,

4. państwo może tę sprawę unormować jednostronnie, tym bardziej, że istnieje precedens, którego skutki trwają aktualnie, mianowicie austriacka ustawa z roku 1874 o obsadzeniu stanowisk kościelnych.

O. Breitinger nie zgadzał się z motywacją referenta spraw kościelnych. Przechodząc zaś do szczegołów - wskazywał, że rozporządzenie z dnia 13. IX. wcale nie normuje tej sprawy, iż nie istnieją wewnętrznokościelne zasady, które regulowalyby sposób powolywania ka- 
nonicznego przełożonego i jednocześnie zarząd stowarzyszenia, możliwosci wywierania wpływu przez kanonicznego zwierzchnika na zarząd związku są analogiczne do kompetencji namiestnika Rzeszy, który także może sprawić odwolanie zarządu, co się zaś tyczy jednostronnego uregulowania przez państwo, był to atak nie uznany przez Stolicę Apostolską.

Całe zagadnienie sprowadzało się do zasadniczej trudności, że lokalne władze kościelne nie byly kompetentne wchodzic $w$ pertraktacje $z$ władzami państwowymi na temat prawnego unormowania sposobu powoływania wyższych przełożonych kościelnych, które podlega Stolicy Aposolskiej. W statutach zaś musiało się przede wszystkim znaleźć stwierdzenie, jaka instancja kościelna powołuje zarząd stowarzyszenia. Zatem O. Breitinger w sprawie władz kościelnych nie widział innych możliwości rozwiązania rozbieżności pomiędzy Kościolem a państwem, podtrzymywał stanowisko, że przedstawiona kościelna wersja statutu z dnia 25. IV. 1942 r. nie może ulec zmianie.

„§ 6. Zastępca Zarządu

Zarząd może dla swego zastępstwa zamianować stałego zastępcę, który jest odwołalny. Jego uprawnienia nie wygasają razem $z$ wygasnięciem zarządu. Po wejsciu w urzędowanie nowego zarządu (§ 5 ust. 1) wygasa urząd stałego zastępcy".

\section{„§ 7. Główna Rada Kościelna}

1. Do pomocy zarządowi służy węższa i szersza Główna Rada Kościelna, której obradom podlega zakres spraw przyznany przez zarząd. Nie posiadają one jednak, wyłączywszy $\S \S 11$ i 12, prawa decydowania. Członkow węższej i szerszej Głównej Rady Kościelnej powołuje zarząd i mogą być w każdym czasie przez niego odwolani.

2. Do węższej Głównej Rady Koscielnej należą:

a. stały zastępca zarząiu,

b. kierownik Glównej kasy Kościelnej (\$ 8),

c. osoby powolane przez zarząd spośród członków korporacji.

3. Do szerszej Glównej Rady Ko-
„§ 6. Zastępca Zarządu

Zarząd musi dla swego zastępstwa mianować stałego zastępcę, kitóry jest odwolalny. Jego uprawnienia nie wygasają razem $\mathrm{z}$ wygaśnięciem zarządu. Uprawnienia stałego zastępcy wygasają $\mathrm{z}$ chwilą objęcia urzędowania przez nowy zarząd ( $\$ 5$ ust. 1). Stały zastępca jest czlonkiem zarządu $w$ sensie $\S 4$ rozporządzenia z 13.IX. 1941 r. Postanowienie $\S 5$ ust. 1 tegoż statutu o odniesieniu się do namiestnika Rzeszy posiada odpowiednie zastosowanie".

"§ 7. Główna Rada Koscielna

1. Do pomocy zarządowi służy węższa i szersza Główna Rada Kościelna, której obradom podlega zakres spraw przyznany przez zarząd. Nie posiadają one jednak, wyłączywszy $\S \S 11$ i 12 , prawa decydowania. Członków węższej i szerszej Głównej Rady Koscielnej powołuje zarząd i moga być przez niego w kaźdym czasie odwolani.

2. Do węższej Glównej Rady Kościelnej należą: 
ścielnej należą oprocz członków węższej Glównej Rady Kościelnej wymienionych $w$ ust. 2 od a do c jeszcze dalsze osoby powołane przez zarząd spośród członków korporacji.

$\S$ 8. Główna Kasa Kościelna

Zarząd posługuje się $w$ zakresie zarządu majątkiem Główną Kasą Kościelną i wydaje dla niej potrzebne zarządzenia administracyjne.

$\S$ 9. Parafialna Rada Kościelna

1. W poszczególnych parafiach zarząd ustanawia Parafialna Radę Koscielną, do której należą następują czlonkowie:

a. proboszcz jako przewodniczący,

b. zastępca przewodniczącego (najstarszy stażem duchowny pomocniczy),

c. członkowie parafii powołani przez zarząd na wniosek proboszcza. Nominacja może być w każdym czasie cofnięta.

2. Zadania Parafialnej Rady Koscielnej są następujące:

a. spośród członków powołanych przez zarząd wybrać następujących urzędników:

aa. zastępcę przewodniczącego, jeżeli nie ma duchownego pomocniczego,

bb. prowadzącego rachunki,

cc. prowadzącego kancelarię,

b. zarządzać majątkiem parafii, przedyskutować i sporządzić roczny budżet parafii,

c. na wniosek proboszcza powoływać i zwalniać świecką służbę kościelną.

3. Parafialna Rada Kościelna podejmuje uchwały większością glosów obecnych. Jeżeli podczas a. stały zastępca zarządu,

b. kierownik Głownej Kasy Kościelnej (\$ 8),

c. trzy dalsze osoby powolane przez zarząd spośród członków stowarzyszenia religijnego.

3. Do szerszej Głównej Rady Kościelnej należą oprócz wymienionych $w$ ust. 2 członków węższej Głównej Rady Koscielnej cztery dalsze osoby powołane przez zarząd spośród członków stowarzyszenia religijnego. $\S$ 8. Główna Kasa Koscielna Zarząd posługuje się w zakresie zarządu majątkiem Główną Kasą Kościelną i wydaje dla niej potrzebne zarządzenia administracyjne.

\section{§ 9. Parafialna Rada} Kościelna

1. W poszczególnych parafiach zarząd ustanawia Parafialną Rade Kościelną, która składa się z proboszcza jako przewodniczącego i dwóch dalszych członków, z których jednego należy ustanowic jako przewodniczącego. Jeżeli istnieją duchowni pomocniczy, należy ustanowić zastępcą przewodniczącego najstarszego stażem duchownego pomocniczego. Członków Parafialnej Rady Koscielnej, prócz proboszcza i duchownych pomocniczych powołuje się z parafii na wniosek proboszcza. Nominacja może byé w każdym czasie cofnięta. Zadania Parafialnej Rady Koscielnej stanowią:

a. zarządzać majątkiem przeznaczonym dla celów parafii, przedyskutować i spo- 
wyborów jakas kandydatura nie osiągnie większości głosów, należy przeprowadzić wybory tak długo, dopóki okreslona osoba osiągnie przewidzianą większość glos $\delta$ w. Jeżeli istnie równość głosów, rozstrzyga głos przewodniczącego". rządzic roczny budzet parafii.

b. na wniosek proboszcza powoływać i zwalniać świecką służbę kościelną.

3. Parafialna Rada Kościelna uchwala wnioski większoscią głosów. Jeżeli istnieje równość głosów, rozstrzyga głos przewodniczącego".

W tym miejscu referent spraw kościelnych polecił dołączyć do statutu postanowienie o tworzeniu nowych parafii. Zastrzegł się, że jest to sprawa wewnętrznokościelna, lecz założenie nowej parafii mógłby zakwestionować namiestnik Rzeszy. Dlatego $w$ statucie powinno znaleźć: "O tworzeniu nowych parafii należy 4 tygodnie przedtem donieść namiestnikowi Rzeszy z zapytaniem, czy będą wysunięte zastrzeżenia". Po namyśle dr Birk oświadczył, że ostatni fragment zdania rozpoczynający się od słów: „z zapytaniem...” mógłby być pominięty. Nadzór państwa w zakresie erekcji parafii nie został poruszony we wersji statutu przygotowanego przez okupacyjne władze państwowe.

\section{§ 10. Pelnomocnictwo i odpowiedzialność}

1. Prawomocne oświadczenia za- rządu posiadają moc obowiązującą dla korporacji tylko wte$\mathrm{dy}$, jeżeli ich dokonuje zarząd albo stały zastępca zarządu w formie pisemnej $z$ podpisem członka Głównej Rady Kościelnej i $z$ przyłożeniem pieczęci korporacji. W sprawach parafialnych oświadczenia posiadają moc obowiązującą dla korporacji także wtedy, jeżeli są dokonane przez przewodniczącego Parafialnej Rady Kościelnej albo jego zastępcę i jednego członka Głównej Rady Kościelnej, w formie pisemnej i $z$ przyłożeniem pieczęci.

2. W pozostałych sprawach odpowiedzialności korporacji mają zastosowanie przepisy BGB".

\section{$\S 10$. Pelnomocnitwo}

i odpowiedzialność

1. Prawomocne oświadczenia zarządu posiadają moc obowiązującą dla stowarzyszenia religijnego tylko wtedy, jeżeli ich dokonuje zarzad albo stały zastępca zarządu $w$ formie pisemnej z podpisem członka Głównej Rady Kościelnej i z przyłożeniem pieczęci stowarzyszenia religijnego. $W$ sprawach parafialnych oswiadczenia posiadają moc obowiązującą dla stowarzyszenia religijnego wtedy, jeżeli są dokonane przez przewodniczącego Parafialnej Rady Kościelnej albo jego zastępcę i jeđnego członka Głównej Kasy Kościelnej $w$ formie pisemnej i z przyłożeniem pieczęci.

2. W pozostałych sprawach odpowiedzialności stowarzyszenia 
$\S$ 11. Zmiana statutu

Zmiana statutu może być przedsięwzięta przez zarząd tylko $z$ upoważnienia szerszej Głównej Rady Kościelnej. Uchwała szerszej Głównej Rady Kościelnej wymaga większosci $4 / 5$ głosów obecnych i jest tylko prawomocna, jeżeli przynajmniej $3 / 4$ członków szerszej Głównej Rady Koscielnej brało udzial w podjęciu uchwaly.

"§ 12. Rozwiązanie

1. Korporacja może się rozwiązać przez oświadczenie zarządu wobec namiestnika Rzeszy. Do tego jest konieczne, aby zarząd posiadał upoważnienie do takiej deklaracji podjęte przez uchwałę szerszej Głównej Rady Koscielnej. Taka uchwała wymaga większości $4 / 5$ glosów obecnych i jest tylko prawomocna, jeżeli $3 / 4$ członków szerszej Głównej Rady Kościelnej brało udzial $w$ podjęciu uchwaly.

2. W przypadku rozwiązania należy się zatroszczyc, aby majątek korporacji zabezpieczyć zgodnie z jego przeznaczeniem".

„§ 13. Uprawomocnienie statutu

$$
\text { i zmian } w \text { statucie }
$$

Statut i zmiany w statucie staja się prawomocne po zgodzie namiestnika Rzeszy i opublikowaniu przez zarząd. Zarząd określa sposób opublikowania. Może ono nastąpić za pomocą ogłoszenia lub obwieszczenia w kościele." religijnego mają zastosowanie przepisy BGB" ${ }^{47}$.

$\S 11$. Zmiana statutu

Zmiana statutu może być przedsięwzięta przez zarząd tylkơ z upoważnienia szerszej Głównej Rady Kościelnej, wymaga większosci 4/5 głosów obecnych i jest tylko prawomocna, jeżeli przynajmniej $3 / 4$ członków szerszej Glównej Rady Kościelnej brało udział $w$ podjęciu uchwaly.

"§ 12. Rozwiązanie

1. Stowarzyszenie religijne może się rozwiązać przez oświadczenie zarządu wobec namiestnika Rzeszy. W takim przypadku należy się zatroszczyć, aby majątek stowarzyszenia religijnego zabezpieczyć zgodnie $z$ jego przeznaczeniem.

2. Do rozwiązania $w$ sensie ust. 1 jest konieczne, aby zarząd posiadal upoważnienie do takiej decyzji podjęte przez uchwałę szerszej Glownej Rady Koscielnej. Taka uchwała wymaga większości $4 / 5$ glosów obecnych i jest tylko prawomocna, jeżeli 3/4 członków szerszej Głównej Rady Kościelnej brało udział w podjęciu uchwaly".

„§ 13. Postanowienia końcowe

1. Statut wchodzi $w$ życie $z$ dniem ...

2. Zmiany $w$ statucie ( $\$ 11)$ i samorozwiązanie ( $\$ 12$ ) nabierają mocy $z$ chwilą zawiadomienia zarządu o zgodzie namiestnika Rzeszy. Statut, zmiany w statucie i samorozwiązanie może opublikować zarząd za pomoca ogłoszenia lub obwieszczenia $\mathrm{w}$ kosciele."

${ }^{47}$ Bürgerliches Gesetzbuch - Kodeks Cywilny. 
W § 12 poprawki, które podyktował referent spraw kościelnych znalazły wyraz w wersji państwowej statutu. $\$ 13$ mial mieć pierwotnie inną wersję. Do tytułu należało dodać: „i samorozwiazanie”. W treści paragrafu miało być sformułowanie: „Statut, zmiany w statucie i samorozwiązanie stowarzyszenia religijnego ogłasza zarząd po zgodzie namiestnika Reszy i nabierają mocy razem $\mathrm{z}$ opublikowaniem. Opublikowanie..."

\section{Statut polskiego stowarzyszenia religijnego}

Nie znamy projektu statutu, który przygotował bp Dymek i przekazal do urzędu namiestnika Reszy. Najprawdopodobniej był to tekst analogiczny do statutu niemieckich katolików, jeżeli nie identyczny, wyją:wszy różnice wymagane zasadą rozdziału narodowego. Również można przypuszczać, że ten projekt został przekazany we wrześniu 1942 roku ${ }^{48}$. Projekt polskiego stowarzyszenia religijnego we wersji władz okupacyjnych jest znacznie uproszczony $w$ stosunku do tekstu statutu (projektu) dla niemieckich Kościolów. Istotne różnice dotyczą:

1. Organizacja polska ma mieć nazwę - polski Kościół rzymsko-katolicki w okręgu Rzeszy Kraju Warty - (projekt statutu dla niemieckich katolików: Kościół rzymskokatolicki Narodowosci Niemieckiej w okręgu Rzeszy Kraj Warty).

2. Nie ma paragrafu o celu stowarzyszenia (w projekcie koscielnym był, lecz został usunięty).

3. Istnieją różnice $w$ odniesieniu do uprawnień czlonków stowarzyszenia. Paragraf o uprawinieniach członkórw zostal usunięty.

4. Zarząd związku posiada ograniczone uprawnienia (istnieje tylko prawo do reprezentowania stowarzyszenia i zarządu majątkiem).

5. Nie istnieje Główna Kasa Kościelna.

6. Istnieje tylko jedna Rada Kościelna bez organów składowych ze zmniejszoną liczą członków (stały zastępca zarządu - duchowny i 2 dalszych duchownych).

7. Nie ma Parafialnej Rady Kościelnej.

Według zamierzeń władz okupacyjnych przy zatwierdzeniu statutu należy zagwarantować unię pomiędzy osobą zwierzchnika kanonicznego a zarządem stowarzyszenia i zastrzec każdorazowo zawiadomienie namiestnika Rzeszy o powolaniu i odwolaniu czlonk6w Rady Koscielnej ${ }^{49}$.

Charakterystyczny jest również sposób prowadzenia rozmów pomiędzy dr. Birkiem a bpem Dymkiem. Nie wiadomo, ile odbyło się tych spotkań, znane sa tylko bowiem okolicznosci i tresc jednej rozmo-

\footnotetext{
48 ADSS III s. 646-647, przypis 1. Taką hipotezę nasuwa list (znany w streszczenju) bpa D y m k a do abpa Orsenigo z dnia 26 VIII 1942.

4 AGK, Polski katolicki Kościót 1940-1942, 45-48.
} 
wy odbytej 18.X.1942 roku. Poprzedniego dnia funkcjonariusz gestapo zawiadomil bpa Dy $\mathrm{mka}$, aby się stawił $\mathrm{u}$ referenta spraw kościelnych. Zgodnie $\mathrm{z}$ terminem zjawil się tenże policjant i zaprowadził bpa Dymka do urzędu namiestnika Rzeszy. Atmosfera spotkania była nieprzyjazna. Dr Birk nie przyrwitał się z bpem Dymkiem, wyznaczył $\mathrm{mu}$ miejsce przy osobnym stole i odczytal projekt statutu przygotowany przez wladze niemieckie. Zaraz na początku bp Dymek zakwestionował nazwę stowarzyszenia, która z racji kościelnych była nie do przyjęcia, ale otrzymał odpowiedź, że tak musi pozostać. Kiedy dr $\mathrm{B}$ irk powiedział, że paragraf o celach stowarzyszenia zostal skreslony, bp Dymek próbował wyjaśnić, że nie może istnieć stowarzyszenie bez celu, lecz i tutaj stwierdził referent spraw kościelnych, iż $w$ odniesieniu do Polaków tak musi pozostać, jak jest $w$ statucie. W sprawie zarządu stowarzyszenia dr Birk zaakcentowal jedność osoby zwierzchnika kanonicznego i stowarzyszenia oraz w sprawie zatwierdzenia jego zastępcy. Radził upewnic się przed nominacją, czy namiestnik Rzeszy wyrazi zgodę na kandydaturę (,Namiestnik Rzeszy nie tolerowałby, gdyby papież np. zamianował murzyna $z$ Ameryki zwierzchnikiem kościelnym w Kraju Warty"). W sprawie parafii i usunięcia ze statutu kościelnego paragrafu o parafialnej radzie kościelnej, bp D y mek wyrazil protest, lecz dr Birk odpowiedział, że i w tym punkcie statut nie może ulec zmianie: „Czy faktycznie będą istnieć parafie, zostanie jeszcze ostatecznie rozstrzygnięte". Na zakończenie dr Birk zapytal się biskupa, czy się zgadza. Bp Dymek odpowiedział, że już wypowiedział swoje wątpliwości, a właściwie nie może zająć stanowiska, ponieważ nie mial możliwosci sledzic sprawy w spokoju, bowiem nie otrzymał do wglądu projektu władz okupacyjnych. Referent spraw kościelnych uznal, że nie ma nic do wyjaśnienia i można skończyć rozmowę (odpowiedzial: geschlossen).

$\mathrm{Z}$ tego spotkania bp $\mathrm{Dymek}$ wyszedł $\mathrm{z}$ pogłębionym przekonaniem, że nie ma sensu prowadzić rozmów i ubiegać się o uznanie prawne dla polskiej organizacji kościelnej. Był przeświadczony, że garstka duchownych, która jeszcze pozostała i zajmuje się działalnością duszpasterską prędzej czy później zostanie usunięta przez aresztowanie. A zanim to nastąpi, Kośció powinien spełniać swoje zadania bez zaprzątania sobie uwagi formą prawną.

Na spotkaniu 18.X. była też mowa o ordynacji składkowej polskich katolikow. Projekt bpa Dy mka został zupełñie zmieniony. Wersja władz okupacyjnych zakładała, że będzie równa dla wszystkich składka czlonkowska, ustalona przez zarząd stowarzyszenia i zatwierdzona przez namiestnika Rzeszy. Wplaty miałyby być dokonywane na pocztowe konto czekowe. Bp Dymek wysuwał do projektu zastrzeżenia natury technicznej $w$ odniesieniu do realizacji wpłat członkowskich, bowiem trudnosci wynikna $z$ powodu nieznajomości języka niemieckiego, a przy tym utrudnione są możliwości informacyjne $z$ uwagi na faktyczne nie- 
istnienie bardzo wielu parafii ${ }^{50}$. Ostateczne zatwierdzenie ordynacji składkowej było uwarunkowane sfinalizowaniem sprawy statutów.

\section{Stan „przejściowy" do końca okupacji}

Rozporządzeniu namiestnika Rzeszy o stowarzyszeniach religijnych zabrakło właściwej siły działania w życiu Kościoła, ponieważ nie została rozstrzygnięta sprawa statutów ${ }^{51}$. Nieustępliwość istniała zarówno po stronie przedstawicieli Kościoła jak i władz okupacyjnych. Cały problem sprowadzał się do zagadnienia, że władze okupacyjne deklarując różnicę pomiędzy stowarzyszeniem religijnym a rzeczywistością Kościoła w znaczeniu kanonicznym, faktycznie utożsamiały te dwie różne instytucje. Katolicy niemieccy nie mogli się pogodzic z faktem, że nazwą Kościół określa się stowarzyszenie, które zależy od woli namiestnika, składa się tylko z członków pełnoletnich, że przynależność jest zależna od deklaracji przed swieckim urzędnikiem, że zwierzchnik kościelny jest zupełnie zależny od władz świeckich, które każdej chwili mogą go odwolać nie podając nawet powodów i wreszcie trwałośc stowarzyszenia jest uwarunkowana wolą namiestnika Rzeszy ${ }^{52}$. Rozwialy się również złudzenia niemieckich katolików o celowości współpracy z namiestnikiem Rzeszy nad zorganizowaniem statusu prawnego. Niewątpliwie kierowali się dobrymi intencjami, chcieli sobie pomóc, sądząc, że przyjmując formę stowarzyszenia prywatnego uregulują płaszczyznę prawnocywilną $w$ odniesieniu do władz okupacyjnych, jednocześnie zachowując pryncypia kanoniczne. Dalszy kompromis był $\mathrm{w}$ istocie niemożliwy. Ale okazało się, że właściwie chęć szukania kompromisu była oparta na błędnej ocenie sytuacji, zabrakło jej zdolności przewidywania. Znacznie trzeźwiej ocenial sytuację przedstawiciel polskich katolików bp W. Dymek, który nie miał złudzeń w odniesieniu do rzeczywistych celów okupanta i dlatego nie chcial paktować $z$ hitlerowskimi władzami 53 .

Mimo że sytuacja była bez wyjścia, O. B reitinger miał zamiar dalej prowadzić rozmowy $z$ władzami okupacyjnymi, chcąc całą dyskusje ograniczyć do spraw istotnych: natury stowarzyszenia, nazwy "Kosciół" i sposobu powoływania zwierzchnika związku. Miał to byé

\footnotetext{
50 AAWr I A $25 \mathrm{w} 54$, bp Dymek do abpa Orsenigo (brak daty) X 1942.

51 Por. J. Sz il in g, dz. cyt., s. 176-177.

52 AAWr I A $25 \mathrm{w}$ 54, o. B reitinger do ministra Rzeszy spraw wewnętrznych 5 VIII 1944.

58 „Die paar Geistlichen, die noch da sind, sind richtig geweiht und haben auch die rechtmässige Jurisdiktion. Ich schlage vor, dass sie ihre Seelsorge weiter ausüben, bis sie nicht einzeln oder gemeinsam festgenommen werden - ohne sich um den Werein zu kümmern". Tamże, bp D y m e k do abpa Orsenigo X 1942.
} 
tylko manewr taktyczny, pozwalający katolikom niemieckim zyskać na czasie i nie stawać w jawnej opozycji do władz hitlerowskich. Ta linia postępowania zostala zaaprobowana 5.VIII.1943 r. przez Stolicę Apostolską. Spełniając instrukcje watykańskie O. Breitinger zawiadomil 15.X.1943 r. namiestnika Rzeszy o koscielnym punkcie widzenia w odniesieniu do projektu statutu wladz akupacyjnych 54 . Według instrukcji wydanych w Watykanie $16 . X I .1943 \mathrm{r}$. należało przerwać wszelkie pertraktacje z czynnikami Greisera, jeżeli wladze okręgu nie odpowiedzią pozytywnie na żądania katolików ${ }^{55}$. Wspomniane pismo O. Breitingera pozostało bez odpowiedzi ${ }^{56}$. Zatem przerwanie pertraktacji było $z$ jednej strony wynikiem uporczywej postawy niemieckich władz kościelnych, które działały na mocy upoważnień Stolicy Apostolskiej a następnie wygaśnięcia warunków manđatu, a z drugiej strony osłabieniem zainteresowania hitlerowskich władz państwowych, które nie wywieraly presji na podjęcie od nowa rozmów. Oprócz tych istotnych motyiwów trzeba wskkazać dalsze przyczyny ${ }^{57}$.

1. trudności $w$ administracji hitlerowskiej spowodowane brakiem personelu powolanego do Wehrmachtu $\mathrm{w}$ związku $\mathrm{z}$ tragiczną sytuacją na frontach,

2. migracje ludnościowe ze „Starej Rzeszy" w wyniku alianckich nalotów bombowych. Szczelnie izolowana polityka kościelna została zagrożona,

3. akcja protestacyjna chrześcijańskich Kościolów w Kraju Warty do centralnych organów niemieckich oraz poparcie ich zażaleniami władz kościelnych „Starej Rzeszy" na sytuację w Kraju Warty do najwyższych władz III Rzeszy ${ }^{58}$.

\section{Die Rechtslage der katholischen Kirche im Wartheland}

Den im Wartheland bisher bestehenden Religionsgeselischaften und Vereinigungen wurde die rechtlige Anerkennung als Körperschaften des öfftentlichen Lebens von der Seite des Staates entzogen, so dass sie in dieser Eigenschaft nicht mehr auftreten konnten.

Eine neue rechtiche Situation ist geschaffen durch die Verordung des Reichsstatthalters Greiser über religiöse Vereinigungen und Reliogionsgesellschaften im Reichsgau Wartheland vom 13 IX 1941. Diese Verordnung hat die Rechtsfähigkeit im Sinne eines Privatrechtes nur der katholischen Kirche für deutsche Bevölkerung und drei protestantischen Kirchen zuerkannt.

Die genannten Vereinigungen konnten ihre Tätigkeiten in Nazistaat weiterführen nur als private Gemeinschaften ohne jegliche Privilegien

54 ADSS III, s. 844, przypis 1.

55 Tamże, dok. 545, s. 844-845, kard. M a glion e do abpa Orsenigo.

$56 \mathrm{AAWr}$ I A $25 \mathrm{~W}$ 54, Bericht über die Seelsorge der deutschen Katholiken 29 VIII 1944.

57 G ürtle r, dz. cyt., s. 113-1:15.

58 Tamże; AAWr I A 25 R 81, w 54, kard. B e r tram do Kancelarii Rzeszy 14 IV 1943 i 4 X 1943.

13 - Prawo kanoniczne 
oder staatliche Betreuung dazu aber unter sehr strenger und einschränkender Aufsicht der inneren Verwaltung von der Seite der Staatsorgane. Die nazistische Staatsverwaltung hat die Pluralität der kirchlichen Rechtspersonen abgeschafft und an dieser Stelle nur eine juristische Person anerkannt, nämlich die religiöse Vereinigung als Ganzes. Den Bestandteilen dieser Vereinigung dagegen ist diese rechtliche Annerkennung abgesprochen. Das neu entstandene Konfessionsrecht war an einigen Stellen mit den Vorschriften des Kirchenrechts nicht zu vereinbaren sogar mit dem Wesen der Kirche. Laut des obenerwähnten Konfessionsrechtes - die volle Mitgliedschaft einer solchen religiösen Vereinigung konnte nur der erzielen, wer mündig (volljähring) war und eine diesbezügliche Erklärung gegenüber einem Standesbeamten ablegte. Die religiöse Vereinigung konnte sich selbst auflosen, ebenso vom Reichsstatthalter konnte aufgelöst werden. Die Hl. Stuhl hat die vollendeten Tatsachen angenommen in dem Sinne, dass die religiöse Vereinigung eine zivilrechtliche Form der Existenz der Kirche innerhalb eines Staaates darstellt. Die Zustimmung des Apostolischen Stuhls zu den Verhandlungen der Vertretern der örtlichen Kirche mit den politischen Behörden ist davon abhängig ob in den Satzungen der religiösen Vereinigungen zwei folgende Klauseln aufzufinden sind: 1) Die Katholiken unterliegen der kirchlichen Obrigkeit und verbleiben in Verbindung mit dem Hl. Stuhl), 2) Es steht den Katholiken zu sich die innere Grundordnung der Kirche nach den Regeln des kanonischen Rechtes zu gestallten.

Die Verordnung über religiöse Vereinigungen hat den Apostolischen Stuhl zu einem Beschluss veranlasst, die katholische Kirche in den besetzten Gebieten auf zwei Organisationen zu verteilen (polnische bezw. deutsche) mit separaten Verwaltungen und Apostolischen Administratoren, die mit personalen Befugnissen ausgestattet wurden in Bezug auf das ganze Gebiet des Warthelandes.

Die Apostolische Administration für die deutschen Katholiken ist am 18 X 1941 entstanden (der Administrator J. Paech, P. H. Breitinger), für polnische Katholiken ist Weihbischof $W$. Dymek bestimmt, die Administration ist aber niemals verwirklicht, blieb als unerfülltes Postulat. Der Bischof Dymek war nicht imstande die Verfügung des Apostolischen Stuhls zu vollziehen, infolge dessen die Lage blieb unverändert.

Damit aber ist das Rechtsmodel für die Kirche, das zweifellos beispielhaft sein sollte für das ganze Dritte Reich, von den Besatzungsbehörden nicht im vollen Masse verwirklicht, weil man kein Einverständniss in der Frage der Statuten erreichen konnte. Neben organisatorischer und rechtlicher Neuordung ist die bisherige Lage im Bereiche des Tatsachenmaterials unverändert.

Die Existenz der „polnischen” Kirche im Nazistaaat war eine unbestreitbare Tatsache, seine Rechtslage blieb jedoch ungeregelt. Die obenerwähnte Verordunung über religiöse Vereinigungen und Religionsgesellschaften war eine der wichtigsetn Faktoren, derer praktischer Ziel bestand darin, die organisatorische Grundordnung der Kirche im Wartheland abszuschaffen. 